\title{
Assessing the Relationship Between Traditional Citation- based Metrics and New Metrics (Altmetrics / Dimensions / Number of Tweets) in COVID-19 \& Eye Research
}

Ali Riza Cenk Celebi ( $\nabla$ arcenkcelebi@gmail.com )

Acibadem University https://orcid.org/0000-0002-7952-1241

Erkan Bulut

İstanbul Gelişim Üniversitesi: Istanbul Gelisim Universitesi

\section{Sumeyra Koprubasi}

Sancaktepe Şehit Prof Dr İlhan Varank Eğitim ve Araştırma Hastanesi: Sancaktepe Sehit Prof Dr Ilhan Varank Egitim ve Arastirma Hastanesi

Mehmet Dokur

Biruni University Faculty of Medicine: Biruni Universitesi Tip Fakultesi

\section{Research Article}

Keywords: Altmetric Attention Score, Bibliometric, COVID-19, Dimensions, Eye, Twitter

Posted Date: January 18th, 2022

DOI: https://doi.org/10.21203/rs.3.rs-1021430/v1

License: (c) (i) This work is licensed under a Creative Commons Attribution 4.0 International License. Read Full License 


\section{Abstract}

Background: Traditional peer-reviewed publications are the most common forums for disseminating scientific information. With the rising popularity of social media, altmetric studies have gained importance in the assessment of impact values of scientific research. In the framework of COVID-19 and eye research, this study aimed to compare activity on new metrics with traditional bibliometric systems using highly cited publications.

Methods: Using the term "COVID-19 \& Eye," data from articles in last one year (March 2020 to April 2021) were collected from the Web of Science Core Collection (WoS) database. Author name, publication year, major topic, study type, journal name, journal impact factor, H-index, total citation number (TCN), Altmetric Attention Score (AAS), number of tweets (NT) and Dimensions score were studied in the top 100 cited articles list (T100 list). The bibliometric data was visualized using the VOSviewer software. For analysis, the Spearman correlation test and descriptive statistics were used.

Results: In our WoS search, we found 720 articles with the term "COVID-19 \& Eye". The mean TCN and AAS in T100 list were $22.51 \pm 62.41$ and $299.11 \pm 2406.74$, respectively. Total citation number showed moderate positive correlation with AAS and strong positive correlation with NT and Dimensions score $(r=0.427, r=0.806, r=0.877$, respectively, $\mathrm{p}=0.001$ for all). Journal impact factor and $\mathrm{H}$-index showed substantial significant positive correlations with AAS and NT.

Conclusion: AAS, particularly Twitter and Dimensions score have a substantial positive correlation with traditional bibliometric data of COVID-19 and eye research.

\section{Introduction}

Since its discovery in Wuhan, China, in December 2019, the COVID-19 has spread swiftly throughout the world, prompting the World Health Organization (WHO) to declare it a pandemic on March 11, 2020 [1]. COVID-19 is transmitted by close contact, inhalation, and the most common early symptoms of COVID-19 have been documented to be dry cough, dyspnea, fever, and weariness, according to current information [2]. Furthermore, unlike the symptoms of a typical virus infection, COVID-19 patients have been found to have conjunctivitis [3,4]. In addition to that the ocular surface has been suggested as a possible pathway for COVID-19 transfer [5]. Due to these circumstances, COVID-19 and eye research has received more attention. With the emergence of the pandemic, there has been an unusually high number of scientific studies published on COVID-19 and eye research. As a result, assessing an article's impact is very crucial, especially for readers who do not have the time to read all relevant publications. The number of citations has been commonly used to measure the influence of works since the development of citation indexing in the 1960s. A greater impact factor equates to more citations per piece. These measurements are regarded as quality indicators, and they can have a significant impact on funding decisions for individual researchers and departments [6]. Map knowledge domain is a method for charting and displaying bibliometric data, as well as performing co-occurrence analysis and hotspot identification. It informs scholars on research topics, new trends, and the development of new study areas [7].

Bibliometric analyses do not accurately reflect an article's impact outside of academia [8]. An alternative technique is required for rapidly assessing the impact of articles, as well as for quickly selecting and disseminating useful information during the pandemic. Mentions of articles on various social media platforms are included in altmetrics, which were called with the goal of being alternative metrics of publication impact [9]. Alternative metrics, rather than replacing bibliometrics and peer review as indicators of research quality, are meant to be used in conjunction 
with these traditional methods for assessing impact in a certain field [10]. When Altmetric Explorer (Altmetric, London, UK) began to conduct analyses in 2011, the concept of an "Altmetric Attention Score (AAS)" gained attraction. AAS measures the worth of articles that have been shared, debated, and seen on Wikipedia, Mendeley, news, blogs, and social networking sites like Twitter, Facebook, and Pinterest. "Twitter" is an important variable. It was established in 2006 and has been increasingly popular in recent years. Tweeting of research articles could be considered an early proxy of article-level research impact in terms of altmetrics [11-13]. Previous research attempted to forecast how many citations a publication would receive in the future [14]. By the beginning of 2021, there were 187 million daily active Twitter users worldwide, sending 500 million tweets each day on average [15]. Nonetheless, as these platforms acquire global acceptance and use, the ability to collect and analyze data from social media platforms has become critical in identifying topics for medical research [16]. Dimension badges, which are also based on the altmetric system, have recently become popular [17]. It is a research information platform that gathers data on funding, scientific outputs, policies, patents, and awards [18].

In the field of COVID-19 and eye research, there are no published studies examining the correlations between traditional bibliometric analysis (citation count, journal H-index, and impact factor) and new metrics (altmetric analysis / dimensions analysis). We also wanted to see how Twitter affected and correlated with these metrics in terms of scientific knowledge distribution.

\section{Materials And Methods}

\subsection{Study design}

According to the Scottish Intercollegiate Guidelines Network (SIGN), our study is a retrospective clinical investigation with a level of evidence of three or group B [19].

\subsection{Compliance with ethical standards}

Each author certifies that the study was carried out in line with the Ethical Principles of the Helsinki Declaration. This study does not require ethical approval because it is based on a review of existing papers in the literature relating to COVID-19 and eye research.

\subsection{Data collection and analytic tools}

The data were retrieved using the search phrase "COVID-19" then refined the results using the phrase "COVID-19 \& Eye" from the Web of Science Core Collection database (Philadelphia, Pennsylvania, United States) (Date of access: April 8, 2021). Articles with full text were gathered. Original research pieces, case studies, editorials, letters, review articles, and short reports were all featured. Each author read all of the articles carefully, and Pubmed was utilized to find out more about the publications. The top-100 cited articles list (T100 list) was developed with the cooperation of all authors, and the articles were ordered from highest to lowest based on citation number. The information was entered into Microsoft Excel spreadsheets. According to the 2019 Clarivate Journal Citation Reports, the journal impact factors (IF) were recorded. The 2020 Scimago Journal and Country Rank were used to determined the H-index and Q categories of journals. SIGN was used to determine the categories of studies and the level of evidence (19). All T100 publications were thoroughly analyzed and categorized and sorted according to journal name, publication year, first author name, total citation number (TCN), average citation number per year $(\mathrm{ACpY})$, study topic, study type, and quality of evidence. The bibliometric data of the T100 list was visualized using VOSviewer software version 1.6.16 (https://www.voswiever.com). WoS data for the top-100 cited papers was 
obtained in the "Full record and cited references" forms. All of the nations on the T100 list were subjected to bibliometric coupling analysis. In the co-occurrence keyword analysis, a threshold value of 2 was employed. Maps were used to display the results of country coupling and keyword co-occurrence analyzes.

AAS and Dimensions badge score were provided by Altmetric (https://www.altmetric.com/products/freetools/bookmarklet/) and Dimensions (https://app.dimensions.ai/discover/publication) web sites, respectively (Available till April 8, 2021). AAS were calculated automatically on the website using a system based on a weighted average of all of each article's attention. On the altmetric donut, each color represents a different source of attention (Figure 1A). Dimension badge of the highly cited article was shown in another figure (Figure 1B).

\section{3.a. Data Extraction from Articles}

The authors independently read the abstract and full text of each publication found, extracting the following information: overall AAS, Dimension badge score, NTs, publishing journal, journal impact factor (IF), month and year of publication, the language, origin nation, document type (original articles (clinical observational study, basic study, randomized controlled trial, systematic review/meta-analysis, reviews, case reports, letters, news, editorials, etc.), main topics (virus, epidemiology, immunology, transmission, prevention, clinical manifestations, treatment, public health responses, vaccines, etc). To avoid fluctuations in article scores, the Altmetric Explorer search was run on a certain day (8 April, 2021).

\subsection{Statistical analysis}

The majority of the statistical approaches utilized in this investigation were descriptive. In the tables, all of the data was expressed as a percentage, a number, a mean, and a standard deviation (SD). Continuous variables were described using the median and interquartile range (IQRs), whereas categorical variables were defined using percentages. The Mann-Whitney $U$ and Kruskal Wallis tests were used to compare intragroup and intergroup differences. The relationships between total citations, Altmetric ratings, and dimensional badge scores were also investigated. The linear association between times mentioned and Altmetric scores was determined using Spearman correlation coefficients. Univariate linear regression analysis was used to calculate beta coefficients. Analyses were recorded using Microsoft Excel. Account age was the independent variable in our Twitter analysis, while determined correlation coefficients $(r)$ were the dependent variable. The correlation coefficients were evaluated as follows: less than 0.4 indicates a weak association; 0.4-0.6 indicates a moderate relationship; 0.61-0.8 indicates a strong relationship; and 0.81-1.00 indicates an extremely strong relationship [20]. Univariate linear regression analysis was used to calculate beta coefficients. SPSS for Windows version 23 was used to conduct all of the statistical analyses. Statistical significance was defined as $p<0.05$.

\section{Results}

Using the keyword "COVID-19" in our WoS search, we retrieved 99.323 articles between March 2020 and April 2021. When we refined the results by using terms " COVID-19 \& Eye," the number of articles in the WoS database dropped to 720 . The top 100 articles in this result that obtained the most citations according to the WoS database were recorded. For each article, the first author, publication year, TCN, ACpY, AAS, Dimensions Score, NTs were displayed in the T100 list (Table 1). Although no language was specified, it was found that all articles on the T100 list were published in English. In the T100 list, the average rates with each variable's min-max values were recorded as

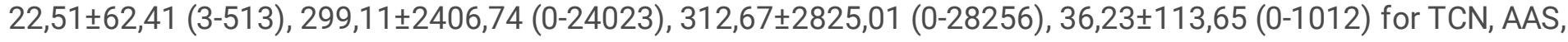


NT and Dimensions, respectively. Due to the outliers in each variable, the median values were also calculated and stated below in each subsection.

\subsection{TCN and AAS analysis}

In the T100 list, the median values for TCN and AAS were 6 and 4.5, respectively. Chu DK et al's [21] article, "Physical distancing, face masks, and eye protection to prevent person-to-person transmission of SARS-CoV-2 and COVID-19: a systematic review and meta-analysis," has the highest TCN of 513 and was published in June 2020. As can be observed, this article omitted COVID-19's ophthalmological characteristics. The second publication, entitled as 'Characteristics of Ocular Findings of Patients with Coronavirus Disease 2019 (COVID-19) in Hubei Province, China,' was published by Wu P et al. [22]. The main focus of this article was on the ophthalmological characteristics of COVID-19 with a TCN of 305. At least three citations were received by every article in the T100 list. The articles by Chu DK et al and Wu P et al get the highest two AAS with the T100 list values of 24023 and 1556 , respectively. There were, however, 20 publications in the T100 list that did not yet have AAS.

\subsection{Twitter analysis}

It was determined that 77 of the T100 list's articles had been shared on Twitter. The median value of NT was 4 . Chu DK et al. [21]'s paper published in the journal of Lancet had the highest NTs (with a number of 28256), which had also the greatest TCN. The paper with the second highest NTs (a number of 922) was also published in journal of Lancet by Maclntyre CR et al. [23] and was entitled as 'Physical distancing, face masks, and eye protection for prevention of COVID-19.' Both of these pieces were related with eye protection. Wu P et al. [22] published the third article with the highest NTs (a number of 715) in the journal of JAMA Ophthalmology, which also had the second highest TCN. This paper focuses on the peculiarities of ocular findings in COVID-19 patients in Hubei Province, China.

\subsection{Dimensions Badge Score}

The median Dimensions score was 10.5, and the article with the most was 1012 and it was the one that currently leads the first place in T100 list according to TCN values. It was published by Chu DK et et al. and entitled as "Physical distancing, face masks, and eye protection to prevent person-to-person transmission of SARS-CoV-2 and COVID-19: a systematic review and meta-analysis."

\subsection{Joumal perspective}

The T100 articles were published in 44 journals in total, with 19 of the T100 articles were published in the Indian Journal of Ophthalmology. It was noteworthy that the journal with the highest median TCN (number of 267.50), AAS (number of 12731), NTs (number of 14589), and Dimensions score (number of 525) was journal of Lancet. On the other hand, journal of Ocular Surface had the highest median TCN (number of 53.50) and Dimensions score (number of 85.5), while journal of JAMA Ophthalmology had the highest AAS (number of 352) and NTs (number of 197) among ophthalmology-specific journals (Table 2).

\subsection{Study types and level of evidence}

Thirty-six articles in the T100 list were original articles according to SIGN. When all articles were classified according to their level of evidence, there was no statistically significant $(p=0.076)$ difference in the median AAS of the four groups. In the same way, there was no significant difference in median TCN between the four groups 
$(p=0.275)$. The median Dimensions score of the four groups did not differ statistically significantly $(p=0.556)$. In terms of twitter analysis, there was no statistically significant difference in median NTs between the four groups $(p=0.14)$. According to these findings, the level of evidence had no significant impact on the AAS, TCN, Dimensions score, and NTs of the articles (Table 3).

\subsection{Research topics}

When we evaluated the T100 list by main topic, the majority of articles were related to clinical features of eye diseases $(n=15)$, precautions for prevention and transmission $(n=14)$ and teleophthalmology $(n=12),($ Table 4). However, the main topic with the highest median AAS, TCN, Dimensions score, and NTs were related to precautions for prevention and transmission.

\subsection{Publication Year and Publication Months}

In 2020, 93 publications were published, with July having the highest number of researches (number of 26). The maximum amount of TCN was found in May (number of 30), but the highest amount of AAS was found in June (number of 32). According to TCN, May was also the month with the highest Dimensions score (number of 45). Parallel to AAS, the greatest NTs were cited in June, according to Twitter data (number of 35) (Table 5.)

\subsection{Correlation analysis}

The results of the correlation analysis were displayed in Table 6 and Figure 2A, 2B and 2C. AAS had a moderate positive link with journal IF and TCN ( $r$ values of 0.458 and 0.427 , respectively, both with $p$ values of 0.001 ), but an extremely strong positive correlation with Dimensions score $(r=0.892, p=0.001)$. Both AAS and NTs had a weak positive connection with $\mathrm{H}$-index ( $\mathrm{r}$ values were 0.215 and 0.096 , p values were 0.034 and 0.348 , respectively). However, NTs were strongly and extremely strongly linked with AAS, Dimensions, TCN, and IF ( $r$ values were 0.998 , $0.878,0.806$ and 0.703 respectively, $p$ values for all were 0.001$)$. Furthermore, NT had a strong positive association with the H-index $(r=0.645, p=0.001)$.

\subsection{Visualization analysis (VOS Viewer)}

For each of the 35 nations in the T100 list, the overall strength of bibliographic coupling relationships with other countries was calculated and visualized (Figure 3A). Larger nodes correspond to countries that are more efficient and productive. The degree of communication and collaboration across countries is shown by the thickness and distance of links between nodes (4). India was the most productive country in terms of document production (26 researches), followed by the United States (20 researches), Italy (15 researches), and Peoples Republic of China (13 researches), but Peoples Republic of China received the most TCN (738 citations). With over 50 TCN, the Peoples Republic of China was followed by Canada, Lebanon, England, India, Singapore, the United States, Italy, Germany, and Australia (TCN of top-10 countries were 738, 567, 513, 313, 282, 237, 198, 162, 85, 78). England was the leading country in terms of international cooperation (3699 link strength).

Using a co-occurrence analysis of high-frequency terms, the hotspots of COVID-19 and eye research were determined. Two was chosen as the minimum number of keyword co-occurrences requirement. 52 of the 205 returned keywords connected to COVID-19 and eye research satisfied the criteria. The network was used to group related keywords, and the colors red, green, blue, yellow, and purple were utilized to symbolize the five major clusters (Figure 3B). The keywords 'covid-19' 'sars-cov-2' and 'conjunctivitis' were the most popular, respectively. 


\section{Discussion}

The novel coronavirus SARS-CoV-2 has sparked an unprecedented worldwide response in research, medicine, public health, and technology since its discovery in December 2019. Given the extremely contagious nature of the infection, as well as the scarcity of knowledge and present lack of viable treatment options, the necessity for timely exchange and distribution of information has been critical. There have been numerous publications published during the pandemic. Citation counts have traditionally been used to identify high-quality and highly valued articles; but, in a fast-pacing pandemic like the COVID-19 pandemic, this strategy is not always practicable. As a result, interest in the COVID-19 issue will continue to grow both in social media and among academics. Traditional citation-based metrics are statistics of "scholarly impact" on an academic-based audience, but altmetrics may be considered possible measures of a "disseminative impact" on the broader populace. The association between traditional bibliometric analysis (citation count, journal H-index, and IF) and altmetric analysis in the area of COVID19 and eye research was explored in this work. The efficacy of combining AAS with TCN in evaluating the top 100 "trending" COVID-19 and eye research publications was investigated in this study. To the best of our knowledge, this is the first study to compare traditional bibliometrics (TCN, journal H-index, and IF) with new metrics like altmetric and dimensions analysis while evaluating publications in the field of COVID-19 and eye research. Previous research has looked into the relationship between citations and altmetrics in different topics, and some has found that while citations and altmetrics are positively correlated to some extent, their correlations are quite weak [24, 25]. According to our findings, and due to the hot topic, AAS was modestly correlated with TCN ( $r 2=0.427)$, however NTs was strongly correlated with TCN $(r=0.806)$. This showed that both peers in the scientific community and members of the general public are on the same page when it comes to knowledge dissemination.

Traditional bibliometric methods are effective for determining the impact value of scientific articles, but they have a number of drawbacks. Before the published article's citation metrics can be measured, a certain length of time must elapse. As a result, bibliometric analysis cannot be used to assess the influence of a recently published paper in its early years. It makes it difficult for researchers to identify compelling papers, keep track of new research topics, and come up with new research topics. Furthermore, self-citation or citation of related authors' papers may unjustly influence citation quantities. As a result, a new technique for quickly analyzing the quality and impact value of the articles is required. Altmetric analysis is a new way of assessing how much attention items get on social media from huge groups of people [26]. Altmetric analysis provides quick insight into an article's worth and influence [27]. We were granted access to the Altmetric database, which houses nearly 31 million research articles from over 36.000 journals and tracks real-time mentions in public policy documents, blogs, mainstream media, online reference managers like Mendeley, research highlights, post-publication peer review platforms like Open Syllabus, YouTube, and social media networks like Facebook. Altmetric.com calculates AAS to determine the overall level of online effect resulting from a certain research output. The AAS is a weighted number that reflects the expected relative degrees of influence of sources on potential readers based on total mentions of a story across multiple online media (e.g., default weights of: 8 for news outlets, 5 for science blogs, 3 forWikipedia or policy documents, 1 for Twitter, and 0.25 for Facebook).

New developments, fresh ideas, and active study fields are prioritized on social media platforms, particularly on Twitter. We also looked into how COVID-19-related ocular information was disseminated through the global scope of social media via Twitter. In terms of scientific knowledge reliability, we found positive connections between the number of tweets and both traditional and altmetric measures. To summarize; AAS had a week positive connection with $\mathrm{H}$-index $(r=0.215)$ despite having a moderate positive correlation with journal IF $(r=0.458)$ and TCN $(r=0.427)$. However, AAS ( $r=0.998)$, Dimensions score $(r=0.878)$, TCN $(r=0.806)$, IF ( $r=0.703)$, and H-index ( $r=0.645)$ were all 
strongly correlated with NTs. According to these results, items that have been quoted frequently throughout time and are still relevant are more useful on social media and Twitter. While AAS and IF were moderately connected $(r=0.458)$, the NTs and had a strong positive connection $(r=0.703)$. This problem could be explained by the fact that the journal IF is affected by current citations. On Twitter, articles that are still being disputed get a lot more attention. Another explanation is that journals with long-standing Twitter accounts have a higher number of followers. As the number of people who follow you on social media grows, so does your awareness of the journals and your ability to read their articles. It has been discovered that announcing newly published publications on Twitter boosts the number of citations in the years that follow [28, 29]. Furthermore, medical journals with Twitter accounts have a higher IF, and there is a positive relationship between journal IF and the number of Twitter followers [30-32].

In terms of the NTs vs. TCN debate, our findings were contradictory with some of the existing literature. The relationship between NTs and TCN was studied by Haustein et al. [33] to be relatively modest. According to Thelwall [34] who has completed over a hundred studies on social media analytics, there was a negative association between NTs and TCN due to the long time required for citation, as opposed to the instantaneous sharing on Twitter. This could be explained by the subject of study. We looked into a topic that was threatening the world, and not only the scientific community, but also the general population, were interested.

In terms of the AAS vs. TCN comparison, our findings are in line with some of the earlier literature. Previous research has found a link between AAS scores and traditional citation count. In their investigation, Kolahi et al. [35] found a statistically significant positive connection between AAS and TCN. As a result of the rise of social media, they believed the strength of this association will increase in the near future. In the altmetric investigation of the realm of pediatric dental research from 2014 to 2017, Gargovich et al. [36] discovered a rising positive association between AAS and TCN. In another malnutrition investigation, Suzan et al. [37] discovered a statistically significant positive association between AAS and TCN, as well as journal IF. Both AAS and NTs were found to have a favorable relationship with $\mathrm{ACpY}$, journal IF, and $\mathrm{H}$-index. These data demonstrate that altmetric and bibliometric characteristics are frequently consistent and linked. Users of social media pay more attention to stories that are still being debated and are current. However, it is crucial to note that all of these studies have concluded that AAS is most successful when used in conjunction with established bibliometric measures, and that AAS should not be used simply to determine the quality of an article.

Although AAS can be used to determine how broadly an item has been disseminated, the correlation between TCN and NTs was lower in our study, suggesting that AAS is less beneficial than NTs. This could be due to a variety of factors. There are various obstacles to the usability of AAS, including the heterogeneity of the platforms used by Altmetric to generate the score, the dynamic nature of AAS, and the fact that many of the platforms we looked at (e.g., Twitter, Facebook, etc.) were not geared toward academics. AAS uses Twitter as one of its sources. The substantial relationships between citation count and Mendeley citations, as well as citation count and Dimensions citations, were not surprisingly given the platforms that Altmetric uses to construct its weighted score and those that the scientific community considers interesting. Mendeley and Dimensions are two well-known websites that scientific academics use to find, organize, and cite previously published research. In comparison to other platforms (such as Twitter or Facebook), which appeal to a broader demography of the general public, these sites attract a more professional group of users who often work in the biomedical scientific sector. Dimensions, a new online scholarly platform for articles, grants, clinical trials, and patents, was introduced in January 2018 by Digital Science, with free partial online access. According to a recent publication, Dimensions' academic database component appears to be a viable alternative to WoS for general citation analysis and citation data in support of 
certain sorts of research evaluations [38]. We discovered a strong link between TCN and Dimensions score $(r=0.877)$ in our research. In addition, the AAS $(r=0.892)$ revealed a strong association with the Dimensions score, too.

Our research also discovered that during the early stages of the pandemic, the T100 altmetric publications on COVID-19 were published more regularly between March and July 2020. A total of 66 articles were published during the early stages of the pandemic, with the remainder appearing subsequently (between August and December 2020). This could be due to the public's increased interest in and desire for knowledge about the novel infectious disease during the early stages of the pandemic.

COVID-19 has sparked a rapid response from the academic and scientific communities in terms of gathering evidence to assist and inform. To establish which issues, attract much more attention in the research and the general trend, it is necessary to categorize the T100 list according to the key topic groups. The bulk of articles $(n=15)$ were on "clinical aspects of COVID-Eye disease," while the main issue with the highest median AAS, median TCN, median Dimensions score, and NTs was about "precautions for prevention and transmission." This was simply interpreted to mean that the community was far more interested in eye-based preventative strategies.

India had the most articles in numbers in T100 list in our analysis. The People's Republic of China, on the other hand, had the highest TCN (738 citations). China's dominance can be attributed to its vast population, massive scientific output, and large online community. Furthermore, because COVID-19 was originally reported in Wuhan, a slew of important studies by Chinese academics were published in early 2020.

Although original articles accounted for 59 of the altmetric top 100 COVID-19 \& Eye articles, there were a variety of document kinds in our list of the altmetric top 100 COVID-19 \& Eye articles, including original articles, letters, case reports, editorials, and news. The public's diversified and broad interests in COVID-19 are reflected in this. Scientific papers, in particular, that provide newer and easier-to-understand information, attract the largest audiences in online media. This is in contrast to the majority of traditional citation studies, which found that reviews were the most frequently quoted [39]. Although public interests cover a wide range of topics, the treatment and clinical manifestations of COVID-19 were the ones that appeared most frequently in the top altmetric articles, highlighting the importance of clinical management among the public and reflecting their fear and anxiety about the global spread of the unknown virus.

Social media may become an increasingly significant aspect of public health in the case of the COVID-19 outbreak [40]. People utilize social media not only to express their personal feelings and ideas, but also to find out more about the outbreak. Due to the widespread quarantines imposed around the world as a result of the virus's rapid spread, social media platforms have emerged as one of the most important information channels to the world and among users for all-around, real-time, non-physical communication. There are 3.5 billion active social media users worldwide, or around 45 percent of the global population, and social networking websites are one of the most popular Internet activities with the highest user engagement [41]. The rapid adoption of social media has increased the visibility of public-facing media environments [42]. Because information sharing and dissemination about the novel coronavirus occurs simultaneously inside social media networks, social media platforms may be the greatest venues to learn about people's interests and worries regarding the advent of the new epidemic. Twitter is one of the most popular social media platforms because it encourages interactions between online users, and because it has little access limitations, any users or accounts can become opinion leaders or influential by acting as a network information or communication center [43]. Because of its widespread use and relatively open data policies, Twitter 
has become a "model organism" for research. It has risen in popularity in the recent decade because it allows users to easily share content and follow accounts, topics, and discussions that are relevant to their interests. As a result of the increased use of Twitter for professional purposes, academics and physicians have begun to use it more frequently for scientific information transmission in recent years. Twitter breaks down academic barriers by allowing scientists and doctors from all around the world to communicate and discuss research ideas. In 2020, 71.9 percent of 160 ophthalmologists had social media accounts, according to research [44]. Many medical journals have their own Twitter accounts as well [45]. At least once, about $20 \%$ of all published papers are notified on Twitter [46]. According to recent research, journals with a large Twitter presence also have a high AAS [47]. This outcome is also consistent with earlier research [48]. This conclusion is backed up by our statistics. During our research, we discovered that publications published in journals that used Twitter as the most popular social media channel received the most mentions for the top ten articles. In our research, 77 of the T100 stories were shared on Twitter. Chu DK et al. published the highest NTs paper (with a number of 28256) in the journal of Lancet, which was also the research with the highest TCN. Wu P et al. submitted the second highest TCN and third highest NTs article in journal of JAMA Ophthalmology, detailing the features of ocular findings of COVID-19 patients in Hubei Province, China. Journal of JAMA Ophthalmology also has a Twitter account, which it uses frequently, however it has a minimal impact on the community. However, it is worth noting that the first and second publications with the greatest NTs were both published in journal of Lancet, a general medicine journal that was not specialized in the field of ophthalmology.

During the COVID-19 pandemic, however, social media had a negative side-rumors, stigma, conspiracy theories, and so on. When dealing with a pandemic outbreak, such disinformation can have major consequences for individuals and communities [49]. Unfortunately, the quality of research conducted and published during the COVID19 epidemic is a problem that must be overlooked. Because of the exponential growth of publications linked to COVID-19, a shortage of experts accessible for peer review, and the requirement for speedy publication during the epidemic, scientific publication has become problematic [50]. As a result of these issues in the present publishing environment, a huge number of published works have been corrected or retracted [51]. The publishing of widespread inaccurate data, whether due to honest error or intentional wrongdoing, could lead to a significant shift in the direction of future studies and clinical decision-making, thereby affecting patient care.

Despite these drawbacks, social media is a particularly effective method for disseminating intellectual works widely [52]. As a result, our ranking of the top 100 altmetric COVID-19 and eye articles offers insight into the spread of scientific knowledge via online media over a certain time period following the appearance of a novel infectious disease.

\section{Limitations}

There are some limitations in our research. To begin, we only used data from Altmetric.com to evaluate alternative measures. We chose it due to its widespread use and incorporation of a diverse set of web channels. If we had utilized alternative altmetric tools that aggregate and offer article-level metrics, such as PlumX, ImpactStory, and PLoS Impact Explorer [53], our results would have been slightly different. Secondly, we identified scientific publications connected to COVID-19 and eye research by using precise search phrases. As a result, some possible articles may have been overlooked due to their usage of other phrases or keywords. Other constraints arise when it comes to using Twitter. Twitter is not accessible in a number of countries, including China. This may explain why China's advantage in research publication activity was overlooked in comparison to other regions. Other social media platforms, such as WeChat and Sina Weibo, are used in China; however, information on their use in China is 
restricted at this time. Future research is needed to evaluate social media activity on these alternative platforms, as well as their relationship with publications and how they compare to Twitter usage in other countries, such as the United States (where Twitter is not banned). Finally, we didn't go into great length on Twitter demographics. Measuring the number of Twitter accounts' followers could aid in calculating the number of individuals contacted and the spread of the articles. It could be beneficial to look at the ages, genders, and geographic areas of Twitter account owners to see what's trending for certain target groups. To undertake thorough Twitter studies, including people types, number of follows, and geographical location of Twitter users, further altmetric research is required. This research only looks at the link between tweets and article citations.

\section{Conclusion}

The demand for knowledge about COVID-19 and eye research has resulted in a significant increase in the number of papers. This study revealed patterns in the use of social media and publications for rapid knowledge distribution during a worldwide pandemic of infectious disease, using both new metrics and traditional metric. As the globe grapples with this extraordinary public health crisis, our research has examined shifting global tendencies away from traditional methods of spreading knowledge (e.g., through publications) and toward more modern methods, particularly among the Ophthalmology community. Twitter and other social media technologies can be useful for disseminating information and informing audiences in real time and in a participatory way, something that isn't always possible with more traditional techniques (ie, scientific publications).

Our research provides a complete list and analysis of the top 100 altmetric papers on COVID-19 and eye research; so, providing crucial information about scientific knowledge transmission during a pandemic caused by this new virus.

Tweets should also be viewed as a metric for social influence and knowledge translation, as well as a way to gauge public interest in a particular topic, whereas citations should be viewed as a metric for scholarly impact. Because of their potential to reflect evidence of broad public range, tweet counts are one of the most intriguing altmetric variables.

In summary, employing altmetric analysis and paying attention to Twitter analysis in addition to traditional bibliometric analyses in the evaluation of papers provides scholars a plethora of knowledge regarding hot issues in COVID-19 and eye research.

\section{Declarations}

\section{Financial Disclosure}

Each author declared that there is no financial support or funding in this study.

\section{Declaration of Interest}

The authors herein declare that they have no conflict of interest and no proprietary or commercial interest in any materials discussed in this article. The authors alone are responsible for the content and writing of the paper.

\section{Data availability statement}


Data of the articles were received from Web of Science (WoS) Core Collection database, and altmetric scores were received from "Altmetric.com".

\section{Authors' contributions}

Ali Riza Cenk Celebi, Erkan Bulut, Sumeyra Agca collected the data and wrote the paper. All of the authors contributed to data collection, interpreting results and reviewing the paper. All authors read and approved the final manuscript

\section{References}

1. WHO Novel coronavirus (2019) -nCoV) situation report - 51 (11 March 2020). Geneva: World Health Organization; 2020 https://www.who.int/docs/default-source/ coronaviruse/situation-reports/20200311-sitrep51-covid- 19.pdf

2. Chen N, Zhou M, Dong X et al (2020) Epidemiological and clinical characteristics of 99 cases of 2019 novel coronavirus pneumonia in Wuhan, China: a descriptive study. Lancet (London, England) 395:507-513

3. Wu P, Duan F, Luo C et al (2020) Characteristics of ocular findings of patients with Coronavirus disease 2019 (COVID-19) in Hubei Province China. JAMA Ophthalmol 138:575-8

4. Chen L, Liu M, Zhang Z et al (2020) Ocular manifestations of a hospitalised patient with confirmed 2019 novel coronavirus disease. Br J Ophthalmol 104:748-751

5. Mirza E, Mirza GD, Belviranli S, Oltulu R, Okka M (2021) Ocular-symptoms-related Google Search Trends during the COVID-19 Pandemic in Europe. Int Ophthalmol 41:2213-2223

6. Powell AGMT, Bevan V, Brown C, Lewis WG (2018) Altmetric versus bibliometric perspective regarding publication impact and force. World J Surg 42:2745-6

7. Zhang XD, Wang CX, Jiang HH, Jing SL, Zhao JY, Yu ZY (2021) Trends in research related to high myopia from 2010 to 2019: a bibliometric and knowledge mapping analysis. Int J Ophthalmol 14:589-599

8. Wang J (2013) Citation time window choice for research impact evaluation. Scientometrics 94:851-872

9. Eyre-Walker A, Stoletzki N (2013) The assessment of science: The relative merits of post publication review, the impact factor, and the number of citations. PLoS Biol 11:e1001675

10. Konkiel S (2016) Altmetrics: diversifying the understanding of influential scholarship. Palgrave Commun 2:16057

11. Eysenbach G (2011) Can tweets predict citations? Metrics of social impact based on Twitter and correlation with traditional metrics of scientific impact. J Med Internet Res 13:e123

12. Shuai X, Pepe A, Bollen J (2012) How the Scientific Community Reacts to Newly Submitted Preprints: Article Downloads, Twitter Mentions, and Citations. PLoS ONE 7:1-8

13. Trueger NS, Thoma B, Hsu CH, Sullivan D, Peters L, Lin M (2015) The altmetric score: A new measure for articlelevel dissemination and impact. Ann Emerg Med 66:549-553

14. Priem J, Piwowar H, Hemminger B Altmetrics in the wild: An exploratory study of impact metrics based on social media. Metrics 2011: Symposium on. Retrieved fromhttp://jasonpriem.com/self-archieved/PLosaltmetrics-sigmetrics 11-abstract.pdf

15. Taneja SL, Passi M, Bhattacharya S, Schueler SA, Gurram S, Koh C (2021) Social Media and Research Publication Activity During Early Stages of the COVID-19 Pandemic: Longitudinal Trend Analysis. J Med 
Internet Res 23:e26956

16. Pershad Y, Hangge PT, Albadawi H, Oklu R (2018) Social medicine: Twitter in healthcare. J Clin Med 7:121

17. Hook DW, Porter SJ, Herzog C (2018) Dimensions: building context for search and evaluation. Frontiers in Research Metrics and Analytics 3:23

18. Depoux A, Martin S, Karafillakis E, Preet R, Wilder-Smith A, Larson H (2020) The pandemic of social media panic travels faster than the COVID-19 outbreak. J Travel Med 27:taaa031

19. Scottish Intercollegiate Guidelines Network (SIGN 50). In: a guideline developer's handbook: Healthcare Improvement Scotland; [cited Nov 2011; Apr 2021]. Available from: http://www.sign.ac.uk/assets/

20. Frapporti G, Linnartz LAM, Vriend SP (1991) SPEARMEN-a dBase program for computation and testing of Spearman rank correlation coefficient distributions. Comput and Geosci 17:569-589

21. Chu DK, Akl EA, Duda S, Solo K, Yaacoub S, Schünemann HJ (2020) COVID-19 Systematic Urgent Review Group Effort (SURGE) study authors. Physical distancing, face masks, and eye protection to prevent person-toperson transmission of SARS-CoV-2 and COVID-19: a systematic review and meta-analysis. Lancet 395:19731987

22. Wu P, Duan F, Luo C, Liu Q, Qu X, Liang L, Wu K (2020) Characteristics of Ocular Findings of Patients With Coronavirus Disease 2019 (COVID-19) in Hubei Province, China. JAMA Ophthalmol 138:575-8

23. Maclntyre CR, Wang Q (2020) Physical distancing, face masks, and eye protection for prevention of COVID-19. Lancet 395:1950-1

24. Thelwall M, Haustein S, Larivière V, Sugimoto CR (2013) Do Altmetrics Work? Twitter and Ten Other Social Web Services. PLoS ONE 8:e64841

25. Costas R, Zahedi Z, Wouters P (2015) Do “Altmetrics" Correlate with Citations? Extensive Comparison of Altmetric Indicators with Citations from a Multidisciplinary Perspective. J Assoc Inf Sci Technol 66:2003-2019

26. Moon JY, Yoon DY, Hong JH et al (2021) The Most Widely Disseminated COVID-19-Related Scientific Publications in Online Media: A Bibliometric Analysis of the Top 100 Articles with the Highest Altmetric Attention Scores. Healthcare 9:239

27. How are outputs scored? (2020) Altmetric.com. https://help.altmetric.com/support/solutions/articles/6000232839-how-are-outputsscored-.Updated September 17, Accessed February 13,2021

28. Hayon S, Tripathi H, Stormont IM, Dunne MM, Naslund MJ, Siddiqui MM (2019) Twitter Mentions and Academic Citations in the Urologic Literature. J Urol 123:28-33

29. Paradis N, Knoll MA, Shah C et al (2020) Twitter: A Platform for Dissemination and Discussion of Scientific Papers in Radiation Oncology. Am J Clin Oncol 43:442-5

30. Hughes H, Hughes A, Murphy C (2017) The Use of Twitter by the Trauma and Orthopaedic Surgery Journals: Twitter Activity, Impact Factor, and Alternative Metrics. Cureus 9:e1931

31. Kelly BS, Redmond CE, Nason GJ, Healy GM, Horgan NA, Heffernan EJ (2016) The Use of Twitter by Radiology Journals: An Analysis of Twitter Activity and Impact Factor. J Am Coll Radiol 13:1391-6

32. Duffy CC, Bass GA, Linton KN, Honan DM (2015) Social media and anaesthesia journals. Br J Anaesth 115:940-1

33. Haustein S, Peters I, Bar-llan J, Priem J, Shema H, Terliesner J (2014) Coverage and adoption of altmetrics sources in the bibliometric community. Scientometrics 101:1145-1163 
34. Thelwall M, Fairclough R (2015) The influence of time and discipline on the magnitude of correlations between citation counts and quality scores. Journal of Informetrics 9:529-541

35. Kolahi J, Khazaei S, Iranmanesh P, Kim J, Bang H, Khademi A (2021) Meta-Analysis of Correlations between Altmetric Attention Score and Citations in Health Sciences. Biomed Res Int. ; 2021: 6680764

36. Garcovich D, Adobes Martin M (2020) Measuring the social impact of research in Paediatric Dentistry: An Altmetric study. Int J Paediatr Dent 30:66-74

37. Suzan V, Unal D (2021) Comparison of attention for malnutrition research on social media Versus academia: Altmetric score analysis. Nutr J 82:111060

38. Thelwall M, Dimensions (2018) A competitor to Scopus and the Web of Science? Journal of Informetrics $12: 430-5$

39. Baltussen A, Kindler CH (2004) Citation classics in critical care medicine. Intensive Care Med 30:902-910

40. Seungil Y (2020) Social Network Analysis for Coronavirus (COVID-19) in the United States. Soc Sci Q 101:1642-7

41. Park H, Jung H, On J, Park SK, Kang H (2018) Digital epidemiology: use of digital data collected for nonepidemiological purposes in epidemiological studies. Healthcare Informatics Research 24:253-262

42. Yoon SW, Chung SW (2020) The EU'S public diplomacy in Asia and the world through social media: sentiment and semantic network analyses of official facebook pages of European external action service and EU delegation to the Republic of Korea. Journal of Contemporary Eastern Asia 19:234-263

43. Chong M, Kim HJM (2019) Social roles and structural signatures of top influentials in the \#prayforparis Twitter network. Qual Quant 54:315-333

44. Al-Khersan H, Lazzarini TA, Fan KC et al (2020) Social media in ophthalmology: An analysis of use in the professional sphere. Health Informatics J 26:2967-2975

45. AlFaris E, Irfan F, Ponnamperuma G, Jamal A, Van der Vleuten C, Al Maflehi N (2018) The pattern of social media use and its association with academic performance among medical students. Med Teach 40:77-82

46. Haustein S, Costas R, Larivière V (2015) Characterizing social media metrics of scholarly papers: the effect of document properties and collaboration patterns. PLoS ONE 10:e0120495

47. Dardas LA, Woodward A, Scott J, Xu H, Sawair FA (2019) Measuring the social impact of nursing research: An insight into altmetrics. J Adv Nurs 75:1394-1405

48. Eysenbach G (2011) Can tweets predict citations? Metrics of social impact based on Twitter and correlation with traditional metrics of scientific impact. J Med Internet Res 13:e123

49. Islam MS, Sarkar T, Khan SH et al (2020) COVID-19-Related Infodemic and Its Impact on Public Health: A Global Social Media Analysis. Am J Trop Med Hyg 103:1621-9

50. Sepúlveda-Vildósola AC, Mejĺa-Aranguré JM, Barrera-Cruz C, Fuentes-Morales NA, Rodriguez-Zeron C (2020) Scientific Publications During the COVID-19 Pandemic. Arch Med Res 51:349-354

51. Soltani P, Patini R, Retracted (2020) COVID-19 articles: A side-effect of the hot race to publication. Scientometrics 125:819-822

52. Borku Uysal B, Islamoglu MS, Koc S, Karadag M, Dokur M (2021) Most notable 100 articles of COVID-19: an Altmetric study based on bibliometric analysis. Ir J Med Sci 18:1-7

53. Jobmann A, Hoffmann CP, Künne S, Peters I, Schmitz J, Wollnik-Korn G (2014) Altmetrics for Large, Multidisciplinary Research Goups: Comparison of Crrent Tols. Bibliometrie Prax Forsch 3:1-19

Page $14 / 36$ 


\section{Tables}

Table 1. Top-100 articles by metrics (T100 list) 


\begin{tabular}{|c|c|c|c|c|c|c|c|}
\hline Rank & Title & First Author & Year & $\begin{array}{l}\text { Time } \\
\text { Cited }\end{array}$ & Dimension & $\begin{array}{l}\text { Altmetric } \\
\text { Score }\end{array}$ & $\begin{array}{l}\text { Number } \\
\text { of } \\
\text { Tweets }\end{array}$ \\
\hline 1 & $\begin{array}{l}\text { Physical distancing, } \\
\text { face masks, and eye } \\
\text { protection to prevent } \\
\text { person-to-person } \\
\text { transmission of } \\
\text { SARS-CoV-2 and } \\
\text { COVID-19: a } \\
\text { systematic review } \\
\text { and meta-analysis }\end{array}$ & Chu D.K. & 2020 & 513 & 1012 & 24023 & 28256 \\
\hline 2 & $\begin{array}{l}\text { Characteristics of } \\
\text { Ocular Findings of } \\
\text { Patients With } \\
\text { Coronavirus Disease } \\
2019 \text { (COVID-19) in } \\
\text { Hubei Province, China }\end{array}$ & Wu P. & 2020 & 305 & 487 & 1556 & 715 \\
\hline 3 & $\begin{array}{l}\text { Can the Coronavirus } \\
\text { Disease 2019 } \\
\text { (COVID-19) Affect the } \\
\text { Eyes? A Review of } \\
\text { Coronaviruses and } \\
\text { Ocular Implications in } \\
\text { Humans and Animals }\end{array}$ & Seah I. & 2020 & 182 & 232 & 157 & 110 \\
\hline 4 & $\begin{array}{l}\text { Stepping up infection } \\
\text { control measures in } \\
\text { ophthalmology } \\
\text { during the novel } \\
\text { coronavirus outbreak: } \\
\text { an experience from } \\
\text { Hong Kong }\end{array}$ & Lai T.H.T. & 2020 & 137 & 174 & 123 & 65 \\
\hline 5 & $\begin{array}{l}\text { The evidence of } \\
\text { SARS-CoV-2 infection } \\
\text { on ocular surface }\end{array}$ & Zhang X. & 2020 & 71 & 99 & 8 & 10 \\
\hline 6 & $\begin{array}{l}\text { Effect of COVID-19 } \\
\text { related lockdown on } \\
\text { ophthalmic practice } \\
\text { and patient care in } \\
\text { India: Results of a } \\
\text { survey }\end{array}$ & Nair A. & 2020 & 54 & 69 & 0 & 0 \\
\hline 7 & $\begin{array}{l}\text { All India } \\
\text { Ophthalmological } \\
\text { Society - Indian } \\
\text { Journal of } \\
\text { Ophthalmology } \\
\text { consensus statement } \\
\text { on preferred practices } \\
\text { during the COVID-19 } \\
\text { pandemic }\end{array}$ & Sengupta S. & 2020 & 52 & 64 & 0 & 0 \\
\hline 8 & $\begin{array}{l}\text { Evaluation of ocular } \\
\text { symptoms and } \\
\text { tropism of SARS-CoV- } \\
2 \text { in patients } \\
\text { confirmed with } \\
\text { COVID-19 }\end{array}$ & Hong $\mathrm{N}$. & 2020 & 47 & 64 & 18 & 14 \\
\hline
\end{tabular}




\begin{tabular}{|c|c|c|c|c|c|c|c|}
\hline 9 & $\begin{array}{l}\text { Detection of SARS- } \\
\text { CoV-2 in Human } \\
\text { Retinal Biopsies of } \\
\text { Deceased COVID-19 } \\
\text { Patients }\end{array}$ & Casagrande M. & 2020 & 38 & 56 & 63 & 15 \\
\hline 10 & $\begin{array}{l}\text { ACE2 and TMPRSS2 } \\
\text { are expressed on the } \\
\text { human ocular } \\
\text { surface, suggesting } \\
\text { susceptibility to } \\
\text { SARS-CoV-2 infection }\end{array}$ & Zhou L. & 2020 & 36 & 72 & 58 & 17 \\
\hline 11 & $\begin{array}{l}\text { Ocular } \\
\text { manifestations and } \\
\text { clinical } \\
\text { characteristics of } 535 \\
\text { cases of COVID-19 in } \\
\text { Wuhan, China: a } \\
\text { cross-sectional study }\end{array}$ & Chen L. & 2020 & 36 & 78 & 30 & 2 \\
\hline 12 & $\begin{array}{l}\text { The possibility of } \\
\text { COVID- } 19 \\
\text { transmission from } \\
\text { eye to nose }\end{array}$ & Qing $\mathrm{H}$. & 2020 & 34 & 45 & 26 & 13 \\
\hline 13 & $\begin{array}{l}\text { Conjunctivitis can be } \\
\text { the only presenting } \\
\text { sign and symptom of } \\
\text { COVID-19 }\end{array}$ & Scalinci S. & 2020 & 31 & 48 & 67 & 36 \\
\hline 14 & $\begin{array}{l}\text { The Ocular Surface } \\
\text { and the Coronavirus } \\
\text { Disease 2019: Does a } \\
\text { Dual 'Ocular Route' } \\
\text { Exist? }\end{array}$ & Napoli P.E. & 2020 & 30 & 46 & 14 & 16 \\
\hline 15 & $\begin{array}{l}\text { SARS-CoV-2 in the } \\
\text { ocular surface of } \\
\text { COVID-19 patients }\end{array}$ & Xie H.T. & 2020 & 27 & 40 & 12 & 7 \\
\hline 16 & $\begin{array}{l}\text { Ocular manifestation } \\
\text { as first sign of } \\
\text { Coronavirus Disease } \\
2019 \text { (COVID-19): } \\
\text { Interest of } \\
\text { telemedicine during } \\
\text { the pandemic context }\end{array}$ & Daruich A. & 2020 & 26 & 43 & 31 & 13 \\
\hline 17 & $\begin{array}{l}\text { COVID-19: Limiting } \\
\text { the Risks for Eye Care } \\
\text { Professionals }\end{array}$ & Sadhu S. & 2020 & 24 & 32 & 7 & 9 \\
\hline 18 & $\begin{array}{l}\text { The COVID-19 } \\
\text { pandemic: Important } \\
\text { considerations for } \\
\text { contact lens } \\
\text { practitioners }\end{array}$ & Jones L. & 2020 & 23 & 43 & 500 & 58 \\
\hline 19 & $\begin{array}{l}\text { Physical distancing, } \\
\text { face masks, and eye } \\
\text { protection for } \\
\text { prevention of COVID- } \\
19\end{array}$ & Maclntyre C. & 2020 & 22 & 38 & 1439 & 922 \\
\hline
\end{tabular}


ocular tissues and

secretions: a

systematic review

\begin{tabular}{|c|c|c|c|c|c|c|c|}
\hline 21 & $\begin{array}{l}\text { Sustainable practice } \\
\text { of ophthalmology } \\
\text { during COVID-19: } \\
\text { challenges and } \\
\text { solutions }\end{array}$ & Lim L.W. & 2020 & 19 & 30 & 9 & 13 \\
\hline 22 & $\begin{array}{l}\text { THE OCULAR } \\
\text { MANIFESTATIONS } \\
\text { AND TRANSMISSION } \\
\text { OF COVID-19: } \\
\text { RECOMMENDATIONS } \\
\text { FOR PREVENTION }\end{array}$ & Dockery D.M. & 2020 & 17 & 24 & 12 & 16 \\
\hline 23 & $\begin{array}{l}\text { The ocular surface, } \\
\text { coronaviruses and } \\
\text { COVID-19 }\end{array}$ & Willcox M.D.P. & 2020 & 17 & 26 & 146 & 49 \\
\hline 24 & $\begin{array}{l}\text { COVID-19 emergency } \\
\text { in the cruise's ship: a } \\
\text { case report of } \\
\text { conjunctivitis }\end{array}$ & Salducci M. & 2020 & 15 & 26 & 10 & 1 \\
\hline 25 & $\begin{array}{l}\text { Taking the right } \\
\text { measures to control } \\
\text { COVID- } 19 \text { in } \\
\text { ophthalmology: the } \\
\text { experience of a } \\
\text { tertiary eye care } \\
\text { referral center in Italy }\end{array}$ & Borrelli E. & 2020 & 15 & 26 & 4 & 4 \\
\hline
\end{tabular}

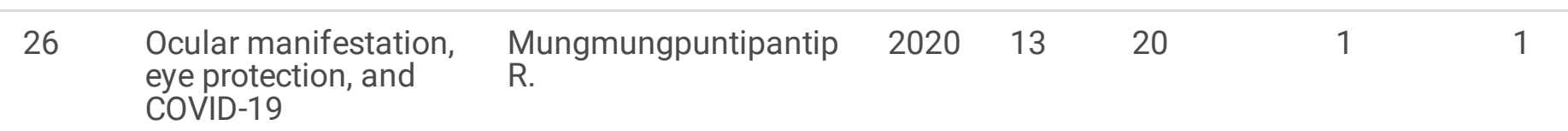

\begin{tabular}{|c|c|c|c|c|c|c|c|}
\hline 27 & $\begin{array}{l}\text { Papillophlebitis in a } \\
\text { COVID-19 patient: } \\
\text { Inflammation and } \\
\text { hypercoagulable } \\
\text { state }\end{array}$ & Insausti-Garcia A. & 2020 & 12 & 17 & 6 & 6 \\
\hline 28 & $\begin{array}{l}\text { COVID-19 and the } \\
\text { Ocular Surface: A } \\
\text { Review of } \\
\text { Transmission and } \\
\text { Manifestations }\end{array}$ & Ho D. & 2020 & 12 & 18 & 57 & 9 \\
\hline 29 & $\begin{array}{l}\text { COVID-19: } \\
\text { Ophthalmological } \\
\text { Aspects of the SARS- } \\
\text { CoV } 2 \text { Global } \\
\text { Pandemic }\end{array}$ & Siedlecki J. & 2020 & 12 & 18 & 6 & 0 \\
\hline
\end{tabular}

\begin{tabular}{|c|c|c|c|c|c|c|c|}
\hline 30 & $\begin{array}{l}\text { Ophthalmology } \\
\text { practice during the } \\
\text { COVID-19 pandemic }\end{array}$ & Safadi K. & 2020 & 12 & 20 & 6 & 8 \\
\hline 31 & $\begin{array}{l}\text { COVID-19 and } \\
\text { ophthalmology: an }\end{array}$ & Kuo I.C. & 2020 & 11 & 19 & 4 & 6 \\
\hline
\end{tabular}


underappreciated

occupational hazard

\begin{tabular}{|c|c|c|c|c|c|c|c|}
\hline 32 & $\begin{array}{l}\text { Symptomatic COVID- } \\
19 \text { in Eye } \\
\text { Professionals in } \\
\text { Wuhan, China }\end{array}$ & Qiao C. & 2020 & 11 & 16 & 52 & 65 \\
\hline 33 & $\begin{array}{l}\text { Detecting SARS-CoV- } \\
2 \text { RNA in conjunctival } \\
\text { secretions: Is it a } \\
\text { valuable diagnostic } \\
\text { method of COVID-19? }\end{array}$ & Guemes-Villahoz N. & 2021 & 11 & 19 & 70 & 86 \\
\hline 34 & $\begin{array}{l}\text { Survey of } \\
\text { ophthalmology } \\
\text { practitioners in A\&E } \\
\text { on current COVID-19 } \\
\text { guidance at three } \\
\text { Major UK Eye } \\
\text { Hospitals }\end{array}$ & Minocha A. & 2020 & 11 & 20 & 5 & 6 \\
\hline 35 & $\begin{array}{l}\text { Retinal vein occlusion } \\
\text { in COVID-19: A novel } \\
\text { entity }\end{array}$ & Sheth J.U. & 2020 & 10 & 13 & 1 & 1 \\
\hline 36 & $\begin{array}{l}\text { To evaluate the effect } \\
\text { of COVID-19 } \\
\text { pandemic and } \\
\text { national lockdown on } \\
\text { patient care at a } \\
\text { tertiary-care } \\
\text { ophthalmology } \\
\text { institute }\end{array}$ & Babu N. & 2020 & 10 & 12 & 0 & 0 \\
\hline
\end{tabular}

\begin{tabular}{|c|c|c|c|c|c|c|c|}
\hline 37 & $\begin{array}{l}\text { Clinical profile and } \\
\text { prevalence of } \\
\text { conjunctivitis in mild } \\
\text { COVID- } 19 \text { patients in } \\
\text { a tertiary care COVID- } \\
19 \text { hospital: A } \\
\text { retrospective cross- } \\
\text { sectional study }\end{array}$ & Sindhuja K. & 2020 & 10 & 15 & 7 & 0 \\
\hline 38 & $\begin{array}{l}\text { COVID-19 Disease } \\
\text { and Ophthalmology: } \\
\text { An Update }\end{array}$ & Amesty M.A. & 2020 & 10 & 18 & 21 & 5 \\
\hline 39 & $\begin{array}{l}\text { Positive detection of } \\
\text { SARS-CoV-2 } \\
\text { combined HSV1 and } \\
\text { HHV6B virus nucleic } \\
\text { acid in tear and } \\
\text { conjunctival } \\
\text { secretions of a non- } \\
\text { conjunctivitis COVID- } \\
19 \text { patient with } \\
\text { obstruction of } \\
\text { common lacrimal } \\
\text { duct }\end{array}$ & $\mathrm{Hu} \mathrm{Y.}$ & 2020 & 10 & 15 & 1 & 1 \\
\hline 40 & $\begin{array}{l}\text { Acute ophthalmic } \\
\text { artery occlusion in a } \\
\text { COVID-19 patient on } \\
\text { apixaban }\end{array}$ & Dumitrascu O.M. & 2020 & 9 & 18 & 2 & 4 \\
\hline
\end{tabular}


COVID-19 and the

Pablo O.E.

2020

9

11

13

3

eye: how much do we

really know? A best

evidence review

42

COVID-19 and the eye

Neri P.

2020

9

11

9

2

immunity: lesson

learned from the past

and possible new

therapeutic insights

\begin{tabular}{|c|c|c|c|c|c|c|c|}
\hline 43 & $\begin{array}{l}\text { Differences in SARS- } \\
\text { CoV-2 } \\
\text { recommendations } \\
\text { from major } \\
\text { ophthalmology } \\
\text { societies worldwide }\end{array}$ & Nguyen A.X. & 2020 & 8 & 7 & 11 & 2 \\
\hline 44 & $\begin{array}{l}\text { Ocular Surface } \\
\text { Expression of SARS- } \\
\text { CoV-2 Receptors }\end{array}$ & Leonardi A. & 2020 & 8 & 16 & 1 & 1 \\
\hline
\end{tabular}

$45 \quad$ Propensity and quantification of Shetty N.

$\begin{array}{lll}2020 & 7 & 7\end{array}$

11

2

aerosol and droplet

creation during

phacoemulsification

with high-speed

shadowgraphy amid

COVID-19 pandemic

46 Tele-consultations in the wake of COVID-

Jayadev C.

$2020 \quad 7 \quad 9$

0

0

19-Suggested

guidelines for clinical

ophthalmology

47 Glycerol-preserved

Gupta N.

$\begin{array}{lll}2020 & 7 & 8\end{array}$

0

0

corneal tissue in

emergency corneal

transplantation: An

alternative for fresh

corneal tissue in

COVID-19 crisis

48 Infection control

measures in

Veritti D.

20207

15

0

0

ophthalmology

during the COVID-19

outbreak: A narrative

review from an early

experience in Italy

\begin{tabular}{|c|c|c|c|c|c|c|c|}
\hline 49 & $\begin{array}{l}\text { Prolonged Use of n95 } \\
\text { Mask a Boon or Bane } \\
\text { to Healthcare } \\
\text { Workers During } \\
\text { Covid-19 Pandemic }\end{array}$ & Kumar S. & 2021 & 6 & 0 & 0 & 0 \\
\hline 50 & $\begin{array}{l}\text { Coping with COVID- } \\
\text { 19: An Italian } \\
\text { Perspective on } \\
\text { Corneal Surgery and } \\
\text { Eye Banking in the }\end{array}$ & Busin M. & 2020 & 6 & 8 & 1 & 1 \\
\hline
\end{tabular}


Time of a Pandemic and Beyond

\begin{tabular}{|c|c|c|c|c|c|c|c|}
\hline 51 & $\begin{array}{l}\text { A Panel of Broad- } \\
\text { Spectrum Antivirals } \\
\text { in Topical } \\
\text { Ophthalmic } \\
\text { Medications from the } \\
\text { Drug Repurposing } \\
\text { Approach during and } \\
\text { after the Coronavirus } \\
\text { Disease } 2019 \text { Era }\end{array}$ & Napoli P.E. & 2020 & 6 & 10 & 0 & 0 \\
\hline 52 & $\begin{array}{l}\text { Conjunctivitis as sole } \\
\text { symptom of COVID- } \\
\text { 19: A case report and } \\
\text { review of literature }\end{array}$ & Ozturker Z.K. & 2020 & 6 & 10 & 66 & 77 \\
\hline 53 & $\begin{array}{l}\text { Face Mask- } \\
\text { Associated Ocular } \\
\text { Irritation and Dryness }\end{array}$ & Moshirfar M & 2020 & 6 & 13 & 567 & 54 \\
\hline 54 & $\begin{array}{l}\text { Relapsing viral } \\
\text { keratoconjunctivitis } \\
\text { in COVID-19: a case } \\
\text { report }\end{array}$ & Guo D. & 2020 & 6 & 10 & 4 & 5 \\
\hline 55 & $\begin{array}{l}\text { COVID-19 } \\
\text { Recommendations } \\
\text { From Ophthalmic and } \\
\text { Plastic } \\
\text { Reconstructive } \\
\text { Surgery Societies } \\
\text { Worldwide }\end{array}$ & Nguyen A.X. & 2020 & 6 & 6 & 3 & 3 \\
\hline 56 & $\begin{array}{l}\text { A review of long-term } \\
\text { corneal preservation } \\
\text { techniques: } \\
\text { Relevance and } \\
\text { renewed interests in } \\
\text { the COVID-19 era }\end{array}$ & Chaurasia S & 2020 & 6 & 6 & 0 & 0 \\
\hline 57 & $\begin{array}{l}\text { Teleconsultation at a } \\
\text { tertiary care } \\
\text { government medical } \\
\text { university during } \\
\text { COVID-19 Lockdown } \\
\text { in India - A pilot study }\end{array}$ & Pandey N & 2020 & 6 & 10 & 1 & 2 \\
\hline 58 & $\begin{array}{l}\text { Demographics and } \\
\text { clinical presentation } \\
\text { of patients with } \\
\text { ocular disorders } \\
\text { during the COVID-19 } \\
\text { lockdown in India: A } \\
\text { report }\end{array}$ & Das AV & 2020 & 6 & 8 & 0 & 0 \\
\hline 59 & $\begin{array}{l}\text { Incorporating Video } \\
\text { Visits into } \\
\text { Ophthalmology } \\
\text { Practice: A } \\
\text { Retrospective } \\
\text { Analysis and Patient } \\
\text { Survey to Assess } \\
\text { Initial Experiences }\end{array}$ & Kalra G & 2020 & 6 & 6 & 10 & 13 \\
\hline
\end{tabular}


and Patient

Acceptability at an

Academic Eye Center

\begin{tabular}{|c|c|c|c|c|c|c|c|}
\hline 60 & $\begin{array}{l}\text { Ocular } \\
\text { manifestations of } \\
\text { coronavirus disease } \\
2019\end{array}$ & Ceran B.B & 2020 & 6 & 17 & 11 & 2 \\
\hline 61 & $\begin{array}{l}\text { Could telehealth help } \\
\text { eye care practitioners } \\
\text { adapt contact lens } \\
\text { services during the } \\
\text { COVID-19 pandemic? }\end{array}$ & Nagra M. & 2020 & 6 & 16 & 11 & 13 \\
\hline 62 & $\begin{array}{l}\text { Virtual Visits in } \\
\text { Ophthalmology: } \\
\text { Timely Advice for } \\
\text { Implementation } \\
\text { During the COVID-19 } \\
\text { Public Health Crisis }\end{array}$ & Bowe T. & 2020 & 6 & 6 & 4 & 6 \\
\hline 63 & $\begin{array}{l}\text { Ophthalmology } \\
\text { Practice During the } \\
\text { Coronavirus Disease } \\
2019 \text { Pandemic: The } \\
\text { University of } \\
\text { Pittsburgh Experience } \\
\text { in Promoting Clinic } \\
\text { Safety and } \\
\text { Embracing Video } \\
\text { Visits }\end{array}$ & WilliamsA.M. & 2020 & 6 & 22 & 5 & 6 \\
\hline 64 & $\begin{array}{l}\text { Ocular } \\
\text { Manifestations and } \\
\text { Clinical } \\
\text { Characteristics of } \\
\text { Children With } \\
\text { Laboratory-Confirmed } \\
\text { COVID-19 in Wuhan, } \\
\text { China }\end{array}$ & Ma N. & 2020 & 5 & 11 & 352 & 197 \\
\hline 65 & $\begin{array}{l}\text { Covid-19-Associated } \\
\text { Retinopathy: A Case } \\
\text { Report }\end{array}$ & Gascon P & 2020 & 5 & 7 & 1 & 1 \\
\hline 66 & $\begin{array}{l}\text { SARS-COV-2 in } \\
\text { Ophthalmology: } \\
\text { Current Evidence and } \\
\text { Standards for Clinical } \\
\text { Practice }\end{array}$ & Torres-Costa S & 2020 & 5 & 3 & 0 & 0 \\
\hline
\end{tabular}

67 Ocular Findings in

COVID-19 Patients: A

Bertoli F

$2020 \quad 5 \quad 5$

1

1

Review of Direct

Manifestations and

Indirect Effects on the

Eye

68 All India

Ophthalmological

Sharma N.

2020

5

5

0

0

Society - Eye Bank

Association of India

consensus statement

on guidelines for 
cornea and

eyebanking during

COVID-19 era

\begin{tabular}{|c|c|c|c|c|c|c|c|}
\hline 69 & $\begin{array}{l}\text { Differential diagnosis } \\
\text { of acute ocular pain: } \\
\text { Teleophthalmology } \\
\text { during COVID-19 } \\
\text { pandemic- A } \\
\text { perspective }\end{array}$ & Murthy S.I. & 2020 & 5 & 6 & 0 & 0 \\
\hline 70 & $\begin{array}{l}\text { Impact of COVID-19 } \\
\text { on a tertiary eye } \\
\text { hospital }\end{array}$ & Sanjay S. & 2020 & 5 & 4 & 0 & 0 \\
\hline 71 & $\begin{array}{l}\text { Sanitizer aerosol- } \\
\text { driven ocular surface } \\
\text { disease (SADOSD)-A } \\
\text { COVID-19 } \\
\text { repercussion? }\end{array}$ & Shetty R & 2020 & 5 & 7 & 2 & 2 \\
\hline 72 & $\begin{array}{l}\text { COVID-19 and eye } \\
\text { banking }\end{array}$ & Chaurasia, Sunita & 2020 & 5 & 6 & 0 & 0 \\
\hline 73 & $\begin{array}{l}\text { Managing } \\
\text { vitreoretinal surgeries } \\
\text { during COVID-19 } \\
\text { lockdown in India: } \\
\text { Experiences and } \\
\text { future implications }\end{array}$ & Agarwal D & 2020 & 4 & 7 & 1 & 0 \\
\hline 74 & $\begin{array}{l}\text { Early impact of } \\
\text { COVID-19 outbreak } \\
\text { on eye care: Insights } \\
\text { from EUROCOVCAT } \\
\text { group }\end{array}$ & Toro M.D. & 2021 & 4 & 8 & 1 & 1 \\
\hline 75 & $\begin{array}{l}\text { PATIENTS WEARING } \\
\text { FACE MASKS } \\
\text { DURING } \\
\text { INTRAVITREAL } \\
\text { INJECTIONS MAY BE } \\
\text { AT A HIGHER RISK } \\
\text { OF } \\
\text { ENDOPHTHALMITIS }\end{array}$ & Hadayer A. & 2020 & 4 & 6 & 12 & 16 \\
\hline 76 & $\begin{array}{l}\text { Teleophthalmology: } \\
\text { an essential tool in } \\
\text { the era of the novel } \\
\text { coronavirus } 2019\end{array}$ & Kalavar M & 2020 & 4 & 8 & 2 & 2 \\
\hline 77 & $\begin{array}{l}\text { Late manifestation of } \\
\text { follicular } \\
\text { conjunctivitis in } \\
\text { ventilated patient } \\
\text { following COVID-19 } \\
\text { positive severe } \\
\text { pneumonia }\end{array}$ & Nayak B & 2020 & 4 & 6 & 0 & 0 \\
\hline 78 & $\begin{array}{l}\text { Change in } \\
\text { Ophthalmic } \\
\text { Clinicians' Attitudes } \\
\text { Toward Telemedicine } \\
\text { During the }\end{array}$ & De Lott L.B. & 2021 & 4 & 5 & 4 & 4 \\
\hline
\end{tabular}


Coronavirus 2019

Pandemic

\begin{tabular}{|c|c|c|c|c|c|c|c|}
\hline 79 & COVID-19 and the eye & Lawrenson J.G. & 2020 & 4 & 7 & 13 & 6 \\
\hline 80 & $\begin{array}{l}\text { Precaution and } \\
\text { prevention of } \\
\text { coronavirus disease } \\
2019 \text { infection in the } \\
\text { eye }\end{array}$ & Chen M.J. & 2020 & 4 & 8 & 3 & 3 \\
\hline 81 & $\begin{array}{l}\text { Pivoting to } \\
\text { teleconsultation for } \\
\text { paediatric } \\
\text { ophthalmology and } \\
\text { strabismus: Our } \\
\text { experience during } \\
\text { COVID-19 times }\end{array}$ & Deshmukh A.V. & 2020 & 4 & 6 & 2 & 2 \\
\hline 82 & $\begin{array}{l}\text { The COVID-19 } \\
\text { Pandemic from an } \\
\text { Ophthalmologist's } \\
\text { Perspective }\end{array}$ & Bacherini D. & 2020 & 4 & 8 & 53 & 69 \\
\hline 83 & $\begin{array}{l}\text { Care for critically III } \\
\text { patients with COVID- } \\
\text { 19: don't forget the } \\
\text { eyes }\end{array}$ & Ting D.S.J. & 2020 & 4 & 5 & 4 & 4 \\
\hline 84 & $\begin{array}{l}\text { Risks Posed to } \\
\text { Corneal Transplant } \\
\text { Recipients by COVID- } \\
\text { 19-Affected Donors }\end{array}$ & Desautels J.D. & 2020 & 4 & 10 & 4 & 5 \\
\hline 85 & $\begin{array}{l}\text { Creating the } \\
\text { Moorfields' virtual eye } \\
\text { casualty: video } \\
\text { consultations to } \\
\text { provide emergency } \\
\text { teleophthalmology } \\
\text { care during and } \\
\text { beyond the COVID-19 } \\
\text { pandemic }\end{array}$ & Kilduff C.L.S. & 2020 & 4 & 5 & 39 & 50 \\
\hline 86 & $\begin{array}{l}\text { Presence of SARS- } \\
\text { CoV-2 RNA in the } \\
\text { Cornea of Viremic } \\
\text { Patients With COVID- } \\
19\end{array}$ & Casagrande M. & 2021 & 3 & 7 & 75 & 75 \\
\hline
\end{tabular}

87 Corneal

transplantation and

Roy A.

20203

4

0

0

eye banking practices

during COVID-19-

related lockdown

period in India from a

network of tertiary

eye care centers

$\begin{array}{lllllll}88 & \begin{array}{l}\text { Retinal involvement } \\ \text { and ocular findings in } \\ \text { COVID-19 pneumonia } \\ \text { patients }\end{array} & \text { Pirraglia M.P. } & 2020 & 3 & 7 & 2\end{array}$




\begin{tabular}{|c|c|c|c|c|c|c|c|}
\hline & $\begin{array}{l}\text { spatter } \\
\text { contamination during } \\
\text { phacoemulsification } \\
\text { cataract surgery in } \\
\text { the era ofCOVID- } 19\end{array}$ & & & & & & \\
\hline 90 & $\begin{array}{l}\text { Visual Field Artifacts } \\
\text { From Face Mask Use }\end{array}$ & Young S.L. & 2020 & 3 & 4 & 8 & 8 \\
\hline 91 & $\begin{array}{l}\text { COVID-19 pandemic: } \\
\text { Ophthalmic practice } \\
\text { and precautions in a } \\
\text { tertiary eye hospital } \\
\text { in Iran }\end{array}$ & Moravvej Z. & 2020 & 3 & 2 & 0 & 0 \\
\hline 92 & $\begin{array}{l}\text { Ocular involvement in } \\
\text { coronavirus disease } \\
2019 \text { (COVID-19): a } \\
\text { clinical and } \\
\text { molecular analysis }\end{array}$ & Shemer A. & 2021 & 3 & 5 & 4 & 5 \\
\hline 93 & $\begin{array}{l}\text { Are eyes the windows } \\
\text { to COVID-19? } \\
\text { Systematic review } \\
\text { and meta-analysis }\end{array}$ & La Distia Nora R. & 2020 & 3 & 6 & 18 & 25 \\
\hline 94 & $\begin{array}{l}\text { Ocular tropism of } \\
\text { coronavirus (CoVs): a } \\
\text { comparison of the } \\
\text { interaction between } \\
\text { the animal-to-human } \\
\text { transmitted } \\
\text { coronaviruses (SARS- } \\
\text { CoV-1, SARS-CoV-2, } \\
\text { MERS-CoV, CoV-229E, } \\
\text { NL63, OC43, HKU1) } \\
\text { and the eye }\end{array}$ & Al-Sharif E. & 2021 & 3 & 3 & 1 & 1 \\
\hline 95 & $\begin{array}{l}\text { Ocular trauma during } \\
\text { COVID-19 stay-at- } \\
\text { home orders: a } \\
\text { comparative cohort } \\
\text { study }\end{array}$ & Wu C. & 2020 & 3 & 5 & 10 & 13 \\
\hline 96 & $\begin{array}{l}\text { Teleconsultation in } \\
\text { primary ophthalmic } \\
\text { emergencies during } \\
\text { the COVID-19 } \\
\text { lockdown in Paris: } \\
\text { Experience with } 500 \\
\text { patients in March and } \\
\text { April } 2020\end{array}$ & Bourdon, $\mathrm{H}$. & 2020 & 3 & 13 & 3 & 3 \\
\hline 97 & $\begin{array}{l}\text { Novel Insights into } \\
\text { the Transmission of } \\
\text { SARS-CoV-2 Through } \\
\text { the Ocular Surface } \\
\text { and its Detection in } \\
\text { Tears and } \\
\text { Conjunctival } \\
\text { Secretions: A Review }\end{array}$ & Guemes-Villahoz N. & 2020 & 3 & 6 & 1 & 1 \\
\hline 98 & $\begin{array}{l}\text { Panuveitis and Optic } \\
\text { Neuritis as a Possible } \\
\text { Initial Presentation of }\end{array}$ & Benito-Pascual B. & 2020 & 3 & 10 & 0 & 0 \\
\hline
\end{tabular}




\begin{tabular}{|c|c|c|c|c|c|c|c|}
\hline 99 & $\begin{array}{l}\text { Optimising } \\
\text { telemedicine in } \\
\text { ophthalmology } \\
\text { during the COVID-19 } \\
\text { pandemic }\end{array}$ & Patel S. & 2020 & 3 & 5 & 0 & 0 \\
\hline 100 & $\begin{array}{l}\text { Impending Central } \\
\text { Retinal Vein } \\
\text { Occlusion in a Patient } \\
\text { with Coronavirus } \\
\text { Disease } 2019 \\
\text { (COVID-19) }\end{array}$ & Invernizzi A. & 2020 & 3 & 8 & 2 & 2 \\
\hline
\end{tabular}

Table 2. Journals of the Top-100 cited articles 


\begin{tabular}{llll} 
AAS & $\begin{array}{l}\text { Total } \\
\text { Citations }\end{array}$ & $\begin{array}{l}\text { Number of } \\
\text { tweets }\end{array}$ & Dimension \\
\hline M [Q1 Q3] & M [Q1 Q3] & M [Q1 Q3] & M [Q1 Q3]
\end{tabular}

\section{Publ. Years}

\begin{tabular}{|c|c|c|c|c|}
\hline 2020 & $5\left[\begin{array}{ll}1 & 14\end{array}\right]$ & $7\left[\begin{array}{ll}5 & 15\end{array}\right]$ & $4\left[\begin{array}{ll}1 & 13\end{array}\right]$ & 11 [7 25] \\
\hline 2021 & $4[170]$ & 4 [3 6] & $4[175]$ & 5 [3 8] \\
\hline \multicolumn{5}{|l|}{ Journals } \\
\hline Acta medıca portuguesa & $0[00]$ & $5[55]$ & $0[00]$ & 3 [3 3] \\
\hline Acta ophthalmologıca & $22[9,528]$ & $35[2241,5]$ & $7,5[1,513,5]$ & 54,5 [30 71] \\
\hline Advances in therapy & $1\left[\begin{array}{ll}1 & 1\end{array}\right]$ & $3[3$ 3 $]$ & $1\left[\begin{array}{ll}1 & 1\end{array}\right]$ & $6\left[\begin{array}{l}6 \\
6\end{array}\right]$ \\
\hline Arquivos brasıleıros de oftalmologia & 13[13 13] & $9[99]$ & $3[3$ 3] & 11 [11 11] \\
\hline Bmj health \& care ınformatıcs & $39[3939]$ & $4[44]$ & $50[5050]$ & 5 [5 5] \\
\hline Bmj open ophthalmology & $11\left[\begin{array}{ll}6 & 18\end{array}\right]$ & $8[3$ 12] & $8[225]$ & 7 [6 20] \\
\hline Clınıca terapeutıca & 10[10 10] & $15[1515]$ & $1\left[\begin{array}{ll}1 & 1\end{array}\right]$ & 26 [26 26] \\
\hline Clınıcal and experımental ophthalmology & $3\left[\begin{array}{l}3 \\
3\end{array}\right]$ & $3[33]$ & $5[55]$ & $6[6$ 6 $]$ \\
\hline Clınıcal and experımental optometry & $146\left[\begin{array}{lll}146 & 146\end{array}\right]$ & $17\left[\begin{array}{lll}17 & 17\end{array}\right]$ & 49[49 49] & $26\left[\begin{array}{ll}26 & 26\end{array}\right]$ \\
\hline Contact lens \& anterıor eye & $255,5[11500]$ & $14,50[623]$ & $35,5[1358]$ & $\begin{array}{l}29,5[16 \\
43]\end{array}$ \\
\hline Current opınıon in ophthalmology & $6[210]$ & $3,5[34]$ & $7,5[213]$ & $6,5[58]$ \\
\hline European journal of ophthalmology & $3,5[0,536]$ & $6,5[59,5]$ & $3,5[0,541,5]$ & $12,5[916]$ \\
\hline Eye & $4,5[47,5]$ & $\begin{array}{l}13[7,5 \\
18,5]\end{array}$ & $5[49,5]$ & $\begin{array}{l}22,5[12,5 \\
25,5]\end{array}$ \\
\hline Eye and visıon & 12 [12 12] & 27 [27 27] & 7 [7 7] & $40[4040]$ \\
\hline $\begin{array}{l}\text { Graefes archive for clınıcal and experımental } \\
\text { ophthalmology }\end{array}$ & 10 [5 67] & $16[9,578]$ & $7,5[1,539]$ & $\begin{array}{l}25[18,5 \\
102]\end{array}$ \\
\hline Idcases & 67 [67 67] & $31[3131]$ & $36[3636]$ & $48[4848]$ \\
\hline Indian journal of ophthalmology & $0\left[\begin{array}{ll}0 & 0\end{array}\right]$ & $6\left[\begin{array}{ll}5 & 10\end{array}\right]$ & $0[0$ 0 0$]$ & 7 [6 12] \\
\hline $\begin{array}{l}\text { Indian journal of otolaryngology and head \& } \\
\text { neck surgery }\end{array}$ & $0\left[\begin{array}{ll}0 & 0\end{array}\right]$ & $6[66]$ & $0[00]$ & $0[00]$ \\
\hline Infectıon control and hospital epıdemıology & $2[04]$ & $7\left[\begin{array}{ll}3 & 11\end{array}\right]$ & $3[06]$ & $10,5[219]$ \\
\hline Internatıonal ophthalmology & $4[19]$ & $3[39]$ & $2\left[\begin{array}{ll}1 & 5\end{array}\right]$ & 5 [3 11] \\
\hline Jama ophthalmology & $352[751556]$ & $5[3305]$ & $197[75715]$ & 11 [7 487] \\
\hline Journal francaıs d ophtalmologie & 17[3 31] & $14,50[326]$ & 8 [3 13] & $28[1343]$ \\
\hline Journal of cataract and refractive surgery & 11[11 11] & $7[77]$ & 2 [2 2] & 7 [7 7] \\
\hline Journal of clınıcal medıcıne & $\begin{array}{l}7\left[\begin{array}{ll}0 & 14] \\
\text { Page 27/36 }\end{array}\right.\end{array}$ & $18[630]$ & $8\left[\begin{array}{ll}0 & 16\end{array}\right]$ & 28 [10 46] \\
\hline
\end{tabular}




\begin{tabular}{|c|c|c|c|c|}
\hline Journal of emergency medıcıne & $12[1212]$ & $17\left[\begin{array}{lll}17 & 17\end{array}\right]$ & $16\left[\begin{array}{ll}16 & 16\end{array}\right]$ & 24 [24 24] \\
\hline Journal of glaucoma & $8[8$ 8] & $3[33]$ & $8[8$ 8 8$]$ & $4[44]$ \\
\hline Journal of medıcal virology & 70[70 70] & $11\left[\begin{array}{ll}11 & 11\end{array}\right]$ & 86 [86 86] & 19 [19 19] \\
\hline Journal of ophthalmology & $1\left[\begin{array}{ll}1 & 1\end{array}\right]$ & $5[55]$ & $1\left[\begin{array}{ll}1 & 1\end{array}\right]$ & $5[55]$ \\
\hline Journal of stroke \& cerebrovascular diseases & $2[2$ 2] & $9[99]$ & $4[44]$ & 18 [18 18] \\
\hline Journal of telemedıcıne and telecare & $0[00]$ & $3[33]$ & $0\left[\begin{array}{ll}0 & 0\end{array}\right]$ & $5[55]$ \\
\hline Journal of the chınese medıcal associatıon & $3[33]$ & $4[44]$ & $3[3$ 3 $]$ & $8[8$ 8 8$]$ \\
\hline Klınısche monatsblatter fur augenhellkunde & $6[66]$ & $12[1212]$ & $0\left[\begin{array}{ll}0 & 0\end{array}\right]$ & 18 [18 18] \\
\hline Lancet & $\begin{array}{l}12731[1439 \\
24023]\end{array}$ & $\begin{array}{l}267,50[22 \\
513]\end{array}$ & $\begin{array}{l}14589[922 \\
28256]\end{array}$ & $\begin{array}{l}525[38 \\
1012]\end{array}$ \\
\hline Ocular ımmunology and inflammatıon & $4,50[160]$ & $10[431]$ & $5,50\left[\begin{array}{ll}1 & 12\end{array}\right]$ & 17 [9 44] \\
\hline Ocular surface & 33[8 58] & $\begin{array}{l}53,50[36 \\
71]\end{array}$ & $13,50\left[\begin{array}{ll}10 & 17\end{array}\right]$ & 85,5 [72 99] \\
\hline Ophthalmıc and physıologıcal optıcs & $13\left[\begin{array}{lll}13 & 13\end{array}\right]$ & $4[44]$ & $6[66]$ & $7[7$ 7 $]$ \\
\hline Ophthalmıc plastıc and reconstructıve surgery & $3[33]$ & $6[66]$ & $3[33]$ & $6[66]$ \\
\hline Ophthalmology & $26,50[152]$ & $8,50\left[\begin{array}{ll}6 & 11\end{array}\right]$ & $33[165]$ & $12[8$ 16] \\
\hline Ophthalmology and therapy & $10[521]$ & $6[66]$ & $6\left[\begin{array}{ll}5 & 13\end{array}\right]$ & 13 [10 18] \\
\hline $\begin{array}{l}\text { Retına-the journal of retınal and vitreous } \\
\text { diseases }\end{array}$ & $12[1212]$ & $4[44]$ & $16\left[\begin{array}{ll}16 & 16\end{array}\right]$ & $6\left[\begin{array}{ll}6 & 6\end{array}\right]$ \\
\hline Scientific reports & $2[2$ 2] & $3[33]$ & $2[2$ 2] & $7[77]$ \\
\hline Telemedıcıne and e-health & $4[44]$ & $5[46]$ & $5[46]$ & $5,5[56]$ \\
\hline Trends ın molecular medıcıne & $53[5353]$ & $4[44]$ & $69[6969]$ & $8[8$ 8 $]$ \\
\hline Vırology journal & $4[44]$ & 6[6 6 $]$ & $5[55]$ & $10[1010]$ \\
\hline
\end{tabular}

Table 3. Intergroup comparison of Level of study according to Scottish Intercollegiate Guidelines Network (SIGN) 


\begin{tabular}{|c|c|c|c|c|c|c|c|c|c|}
\hline & $\begin{array}{l}\text { Number } \\
\text { of } \\
\text { articles }\end{array}$ & $\begin{array}{l}\text { Citations, } \\
\text { median } \\
\text { (IQR) }\end{array}$ & $p^{*}$ & $\begin{array}{l}\text { AAS, } \\
\text { median } \\
(\mathrm{IQR})\end{array}$ & $p^{*}$ & $\begin{array}{l}\text { Dimension, } \\
\text { median } \\
(\mathrm{IQR})\end{array}$ & $p^{*}$ & $\begin{array}{l}\text { Number of } \\
\text { tweets, } \\
\text { median } \\
\text { (IQR) }\end{array}$ & $p^{*}$ \\
\hline $\begin{array}{l}\text { Level } \\
1\end{array}$ & 4 & $\begin{array}{l}17(7,5- \\
267,5)\end{array}$ & \multirow[t]{4}{*}{0,275} & $\begin{array}{l}14(8- \\
12020.5)\end{array}$ & \multirow[t]{4}{*}{0,076} & $\begin{array}{l}21,5(12- \\
518.5)\end{array}$ & \multirow[t]{4}{*}{0,556} & $\begin{array}{l}19(6,5- \\
14140)\end{array}$ & \multirow[t]{4}{*}{0,14} \\
\hline $\begin{array}{l}\text { Level } \\
2\end{array}$ & 13 & $6(4-11)$ & & $11(4-58)$ & & 8 (6-19) & & $13(2-16)$ & \\
\hline $\begin{array}{l}\text { Level } \\
3\end{array}$ & 34 & $6(4-10)$ & & $2,5(1-10)$ & & $10(6-16)$ & & $2(0-10)$ & \\
\hline $\begin{array}{l}\text { Level } \\
4\end{array}$ & 49 & $7(5-17)$ & & $4(1-13)$ & & $11(6-26)$ & & $4(1-9)$ & \\
\hline
\end{tabular}

*Kruskal-Wallis test Test; $\quad \mathrm{p}<0,05$ significant

Table 4.The Top-100 cited articles based on topic categories 


\begin{tabular}{|c|c|c|c|c|c|}
\hline & $\begin{array}{l}\text { Number } \\
\text { of } \\
\text { articles }\end{array}$ & $\begin{array}{l}\text { Citations. } \\
\text { median } \\
\text { (IQR) }\end{array}$ & $\begin{array}{l}\text { AS. } \\
\text { median } \\
\text { (IQR) }\end{array}$ & $\begin{array}{l}\text { Dimension } \\
\text { median } \\
\text { (IQR) }\end{array}$ & $\begin{array}{l}\text { Number } \\
\text { of } \\
\text { tweets. } \\
\text { median } \\
\text { (IQR) }\end{array}$ \\
\hline Clinical features of eye disease & 15 & $6(3-12)$ & $6(2-31)$ & $11(8-18)$ & $4(1-25)$ \\
\hline $\begin{array}{l}\text { Precautions for prevention and transmission in } \\
\text { clinic }\end{array}$ & 14 & $\begin{array}{l}11,5(7- \\
19)\end{array}$ & $3,5(0-69$ & $20(7-30)$ & $2,5(0-6)$ \\
\hline Teleophthalmology & 12 & $4,5(4-6)$ & $2,5(5-7)$ & $6(5,5-9,5)$ & $\begin{array}{l}2,5(1- \\
9,5)\end{array}$ \\
\hline Reorganization of the eye bank's clinical activity & 7 & $5(4-6)$ & $0(0-1)$ & $6(5-8)$ & $0(0-1)$ \\
\hline $\begin{array}{l}\text { Clinical features of eye disease and ocular } \\
\text { tropism }\end{array}$ & 6 & $14(9-179$ & $\begin{array}{l}15,5(12- \\
70)\end{array}$ & $\begin{array}{l}21,5(11- \\
26)\end{array}$ & $15(5-49)$ \\
\hline $\begin{array}{l}\text { Consequence of personal protection equipment } \\
\text { (PPE) use }\end{array}$ & 5 & $5(4-6)$ & $8(2-12)$ & $6(4-7)$ & $8(2-16)$ \\
\hline Transmision dynamics & 5 & $27(7-30)$ & $\begin{array}{l}12(11- \\
14)\end{array}$ & $40(7-45)$ & $1(0-1)$ \\
\hline Virologic features & 5 & $6(5-8)$ & $1(0-1)$ & $10(7-15)$ & $1(0-1)$ \\
\hline Virologic features and ocular tropism & 4 & $\begin{array}{l}20(3,5- \\
37)\end{array}$ & $\begin{array}{l}35,5(7- \\
60,5)\end{array}$ & $31,5(5-64)$ & $\begin{array}{l}10,5(3,5- \\
16)\end{array}$ \\
\hline $\begin{array}{l}\text { Clinical features of eye disease and } \\
\text { transmission dynamics }\end{array}$ & 2 & $\begin{array}{l}188(71- \\
305)\end{array}$ & $\begin{array}{l}782(8- \\
1556)\end{array}$ & $\begin{array}{l}293(99- \\
487)\end{array}$ & $\begin{array}{l}362,5(10- \\
715)\end{array}$ \\
\hline $\begin{array}{l}\text { Clinical features of eye disease and virologic } \\
\text { features and precautions for prevention and } \\
\text { transmission }\end{array}$ & 2 & $\begin{array}{l}18(12- \\
24)\end{array}$ & $\begin{array}{l}32(7- \\
57)\end{array}$ & $25(18-32)$ & $9(9-9)$ \\
\hline $\begin{array}{l}\text { Epidemiological and Clinical features of eye } \\
\text { disease }\end{array}$ & 2 & $\begin{array}{l}23(10- \\
36)\end{array}$ & $\begin{array}{l}18,5(7- \\
30)\end{array}$ & $\begin{array}{l}46,5(15- \\
78)\end{array}$ & $1(0-2)$ \\
\hline Ocular complications of ICU follow up & 2 & $4(4-4)$ & $2(0-4)$ & $5,5(5-6)$ & $2(0-4)$ \\
\hline $\begin{array}{l}\text { Precautions for prevention and transmission in } \\
\text { community }\end{array}$ & 2 & $\begin{array}{l}267,5 \\
(22-513)\end{array}$ & $\begin{array}{l}12731 \\
(1439- \\
24023)\end{array}$ & $\begin{array}{l}525(38- \\
1012)\end{array}$ & $\begin{array}{l}14589 \\
(922- \\
28256)\end{array}$ \\
\hline $\begin{array}{l}\text { The epidemiology of eye disease during } \\
\text { lockdown }\end{array}$ & 2 & $8(6-10)$ & $0(0-0)$ & $10(8-12)$ & $0(0-0)$ \\
\hline $\begin{array}{l}\text { The epidemiology of eye injuries during } \\
\text { lockdown }\end{array}$ & 2 & 3 (3-39 & $\begin{array}{l}5,5(1- \\
10)\end{array}$ & $5,5(5-6)$ & $7(1-13)$ \\
\hline $\begin{array}{l}\text { Clinical features of eye disease and precautions } \\
\text { for prevention and transmission }\end{array}$ & 1 & $4(4-4)$ & $\begin{array}{l}53(53- \\
53)\end{array}$ & $8(8-8)$ & $\begin{array}{l}69(69- \\
69)\end{array}$ \\
\hline $\begin{array}{l}\text { Clinical features of eye disease and } \\
\text { transmission dynamics and precautions for } \\
\text { prevention and transmission }\end{array}$ & 1 & $\begin{array}{l}12(12- \\
12)\end{array}$ & $6(6-6)$ & $18(18-18)$ & $0(0-0)$ \\
\hline Clinical features of eye disease and treatment & 1 & $5(5-5)$ & $1(1-1)$ & $5(5-5)$ & $1(1-1)$ \\
\hline $\begin{array}{l}\text { Clinical features of eye disease and virologic } \\
\text { features }\end{array}$ & 1 & $4(4-4)$ & $3(3-3)$ & $8(8-8)$ & $3(3-3)$ \\
\hline
\end{tabular}




\begin{tabular}{|c|c|c|c|c|c|}
\hline $\begin{array}{l}\text { Epidemiological and virologic features and } \\
\text { precautions for prevention and transmission }\end{array}$ & 1 & $\begin{array}{l}10(10- \\
10)\end{array}$ & $\begin{array}{l}21(21- \\
21)\end{array}$ & $18(18-18)$ & $5(5-5)$ \\
\hline Epidemiological features & 1 & $\begin{array}{l}11(11- \\
11)\end{array}$ & $\begin{array}{l}52(52- \\
52)\end{array}$ & $16(16-16)$ & $\begin{array}{l}65(65- \\
65)\end{array}$ \\
\hline Immunologic characteristics of the eye & 1 & $9(9-9)$ & $9(9-9)$ & $11(11-11)$ & $2(2-2)$ \\
\hline Incidence of COVID 19 in eyecare professionals & 1 & $4(4-4)$ & $1(1-1)$ & $8(8-8)$ & $1(1-1)$ \\
\hline Ocular tropism & 1 & $\begin{array}{l}22(22- \\
22)\end{array}$ & $\begin{array}{l}10(10- \\
10)\end{array}$ & $25(25-259$ & $\begin{array}{l}13(13- \\
13)\end{array}$ \\
\hline Pathogenesis of ocular infection & 1 & $\begin{array}{l}182(182- \\
182)\end{array}$ & $\begin{array}{l}157 \\
(157- \\
157)\end{array}$ & $\begin{array}{l}232(232- \\
232)\end{array}$ & $\begin{array}{l}110 \\
(110- \\
1109\end{array}$ \\
\hline $\begin{array}{l}\text { Precautions for prevention and transmission } \\
\text { and Teleophthalmology }\end{array}$ & 1 & $6(6-6)$ & $5(5-5)$ & $22(22-22)$ & $6(6-6)$ \\
\hline $\begin{array}{l}\text { Precautions for prevention and transmission for } \\
\text { the use of personal therapeutic devices }\end{array}$ & 1 & $\begin{array}{l}23(23- \\
23)\end{array}$ & $\begin{array}{l}500(500- \\
500)\end{array}$ & $43(43-43)$ & $\begin{array}{l}58(58- \\
58)\end{array}$ \\
\hline Socioeconomic and psychological impact & 1 & $5(5-5)$ & $0(0-0)$ & $4(4-4)$ & $0(0-0)$ \\
\hline
\end{tabular}

Table 5. Comparisons of TCN, Altmetric, Dimensions score, and NT on a monthly basis

\begin{tabular}{|c|c|c|c|c|c|c|c|c|}
\hline & \multicolumn{2}{|l|}{ AAS } & \multicolumn{2}{|c|}{ Total Citations } & \multicolumn{2}{|l|}{ Number of tweets } & \multicolumn{2}{|l|}{ Dimension } \\
\hline & M [Q1 Q3] & $P$ & M [Q1 Q3] & $P$ & M [Q1 Q3] & $P$ & M [Q1 Q3] & \\
\hline APR & 12 [6 157] & 0,112 & 27 [12 182] & 0,001 & 8 [7 110] & 0,177 & 40 [20 232] & 0006 \\
\hline AUG & $1\left[\begin{array}{ll}0 & 3\end{array}\right]$ & & $6\left[\begin{array}{ll}5 & 10\end{array}\right]$ & & 0 [0 3] & & 10 [6 15] & \\
\hline DEC & $3\left[\begin{array}{ll}1 & 30\end{array}\right]$ & & 10 [3 36] & & $2\left[\begin{array}{ll}1 & 5\end{array}\right]$ & & 15 [6 15] & \\
\hline FEB & $4[44]$ & & 3,5 [3 4] & & $4,50[45]$ & & $5[55]$ & \\
\hline JAN & $1[170]$ & & $4\left[\begin{array}{ll}3 & 11\end{array}\right]$ & & $1[186]$ & & 8 [3 19] & \\
\hline JUL & $4\left[\begin{array}{ll}0 & 10\end{array}\right]$ & & $7\left[\begin{array}{ll}5 & 17\end{array}\right]$ & & 3,50 [0 9] & & 10 [7 25] & \\
\hline JUN & $32[1,5969,5]$ & & $9,5[522,5]$ & & $35,50[1,5495,5]$ & & $18[7,540,5]$ & \\
\hline MAY & 13 [6 31] & & 30 [12 54] & & $3\left[\begin{array}{ll}0 & 16]\end{array}\right.$ & & 45 [18 69] & \\
\hline NOV & $1[0$ 2] & & 3 [3 5] & & $1[0$ 2] & & $7[4$ 8] & \\
\hline Ост & $2\left[\begin{array}{ll}1 & 8\end{array}\right]$ & & $4\left[\begin{array}{ll}3 & 10\end{array}\right]$ & & $2[18]$ & & $7[4$ 8] & \\
\hline SEP & $10\left[\begin{array}{ll}3 & 12\end{array}\right]$ & & $5,5[46]$ & & $5,50[216]$ & & 7,5 [6 13] & \\
\hline
\end{tabular}

P value was obtained from Kruskal Wallis test. (post hoc test: Dunn).

Table 6. Correlation analysis 


\begin{tabular}{|c|c|c|c|c|c|c|c|}
\hline & & Dimension & Total Citations & IF & H-index & Q category & Twitter \\
\hline \multirow[t]{2}{*}{ AAS } & $\mathrm{p}$ & 0,892 & 0,427 & 0,458 & 0,215 & $-0,444$ & 0,998 \\
\hline & $r$ & 0,001 & 0,001 & 0,001 & 0,034 & 0,001 & 0,001 \\
\hline \multirow[t]{2}{*}{ Dimension } & $\mathrm{p}$ & 1 & 0,877 & 0,260 & 0,169 & $-0,192$ & 0,878 \\
\hline & $r$ & & 0,001 & 0,013 & 0,098 & 0,060 & 0,001 \\
\hline \multirow[t]{2}{*}{ Total Citations } & $\mathrm{p}$ & & 1 & 0,117 & 0,096 & $-0,066$ & 0,806 \\
\hline & $r$ & & & 0,268 & 0,348 & 0,522 & 0,001 \\
\hline \multirow[t]{2}{*}{ IF } & $\mathrm{p}$ & & & 1 & 0,799 & $-0,905$ & 0,703 \\
\hline & $r$ & & & & 0,001 & 0,001 & 0,001 \\
\hline \multirow[t]{2}{*}{$\mathrm{H}$-index } & $\mathrm{p}$ & & & & 1 & $-0,744$ & 0,645 \\
\hline & $r$ & & & & & 0,001 & 0,001 \\
\hline \multirow[t]{3}{*}{ Q category } & $\mathrm{p}$ & & & & & 1 & $-0,523$ \\
\hline & $r$ & & & & & & 0,001 \\
\hline & $\mathrm{p}$ & & & & & & 1 \\
\hline
\end{tabular}

Twitter

AAS: altmetric attention score; TCN: total citation number; ACpY: average citation per year; NTs: number of tweets; IF: journal impact factor *Correlation is significant at the 0.01 level

\section{Figures}




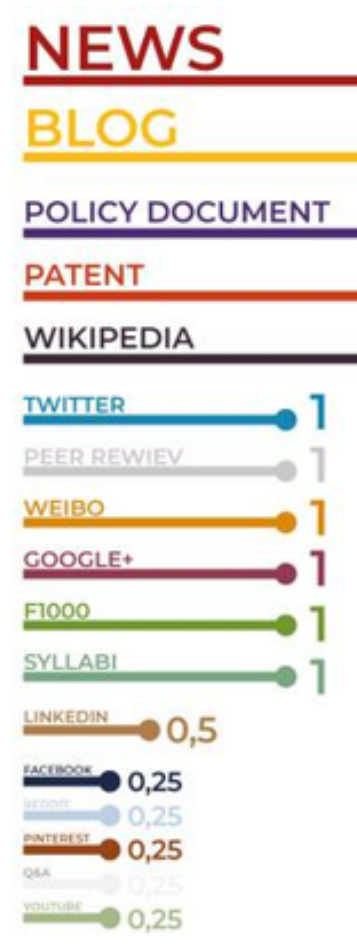

8

Publication metrics

Dimensions Badge

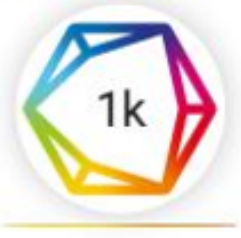

1k Total citations

1k Recent citations

n/a Field Citation Ratio

n/a Relative Citation Ratio

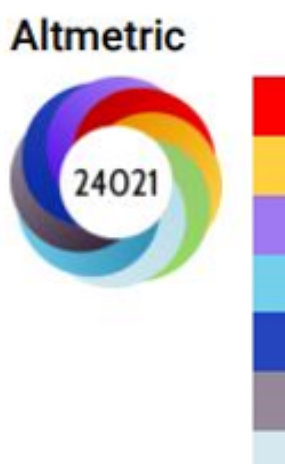

News (676)

Blogs (78)

Policy documents (7)

Twitter (28255)

Facebook (77)

Wikipedia (2)

Reddit (15)

F1000 (1)

Video (7)

Mendeley (2997)

$25 \times 25 \mathrm{~mm}(600 \times 600 \mathrm{DPI})$

Figure 1

Altmetric donuts and dimension badge A. Each color on the altmetric donut symbolizes a distinct source of attention. The weight score for posts of each social media platform is displayed.

B. Altmetric donut and dimension badge of the highly cited article was shown as a sample 

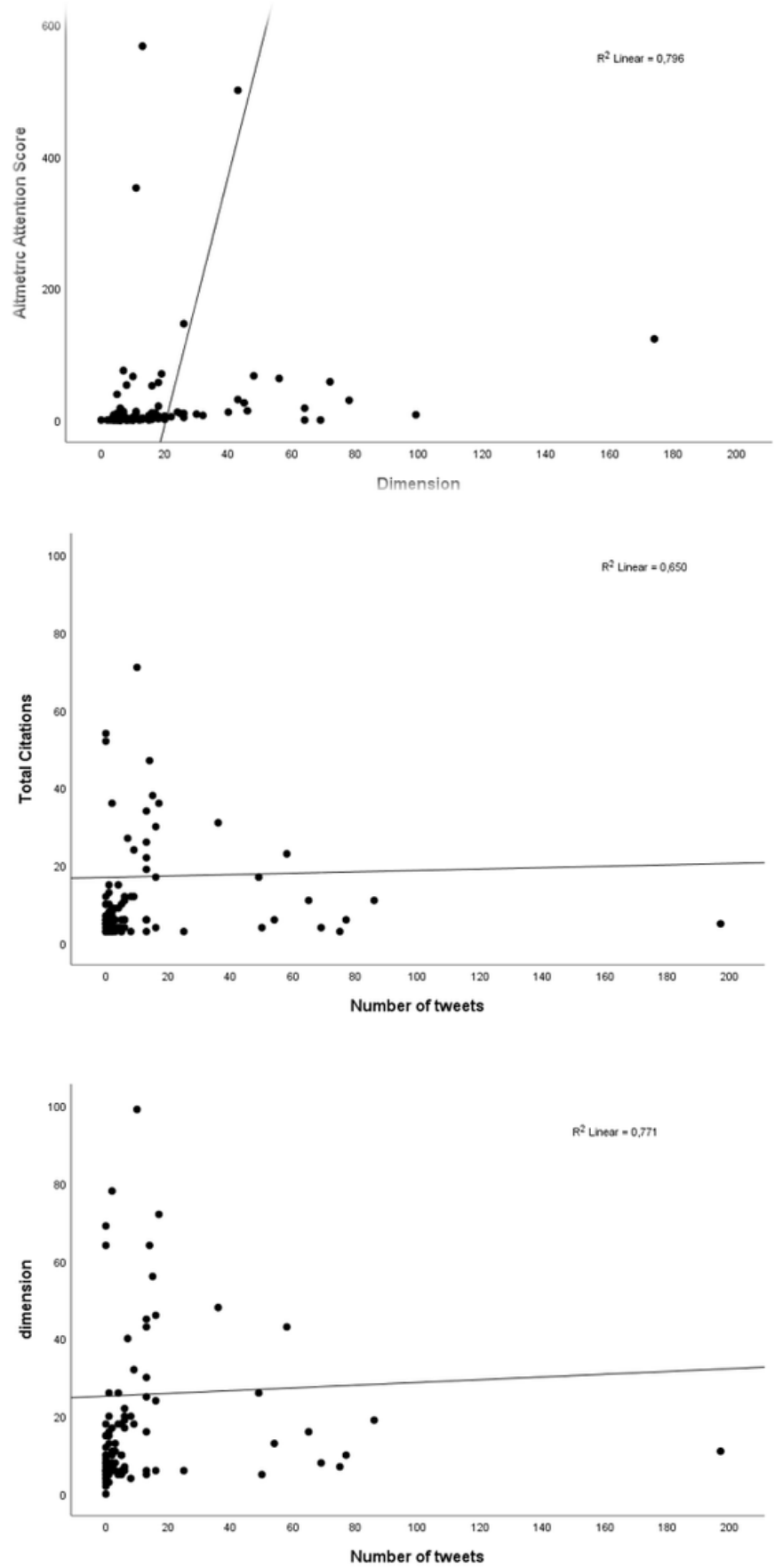

Figure 2

Scatter plot showing relation between Altmetric Attention Score and Dimensions Badge (Figure 2A), Total Citation and Number of Tweets (Figure 2B), Dimensions Badge and Number of Tweets (Figure 2C)

A: There was strong positive correlation between Altmetric Attention Score and Dimensions Badge ( $r=0.892$; $p=0.001)$. According to univariate linear regression analysis $~ 80 \%$ of variation in Altmetric Attention Score was explained by Dimensions Badge. 1 unit increase in Dimensions Badge resulted in 18.90 increase in Altmetric Attention

Score model to estimate Altmetric Attention Score was 
$Y_{\text {Altmetric Attention Score }}=-385.51+18.90 * X_{\text {Dimensions Badge }}$

B: There was strong positive correlation between Total citation and Number of Tweets $(r=0.806 ; p=0.001)$. According to univariate linear regression analysis $\sim 65 \%$ of variation in total citation was explained by Tweets. 1 unit increase in tweets resulted in 0.02 increase in citation

Score model to estimate total citation was

$\mathrm{Y}_{\mathrm{T} \text {. Citation }}=16.94+0.018 * \mathrm{X}$ Number of tweets

C: There was strong positive correlation between citation and Twitter $(r=0.878 ; p=0.001)$. According to univariate linear regression analysis $\sim 77 \%$ of variation in dimension badge was explained by number of Tweets. 1 unit increase in tweets resulted in 0.04 increase in dimension badge

Score model to estimate dimension was

$Y_{\text {Dimension Badge }}=25.19+0.04 * X$ Number of tweets 


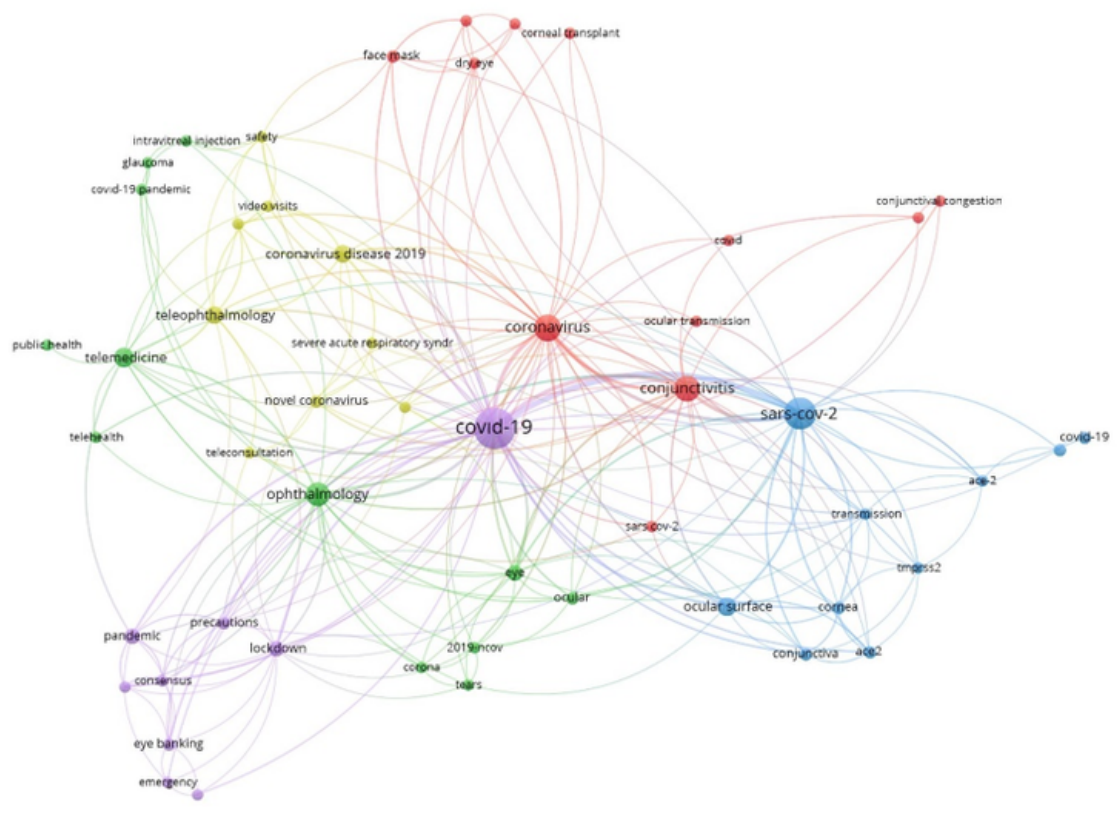

As vosviewer

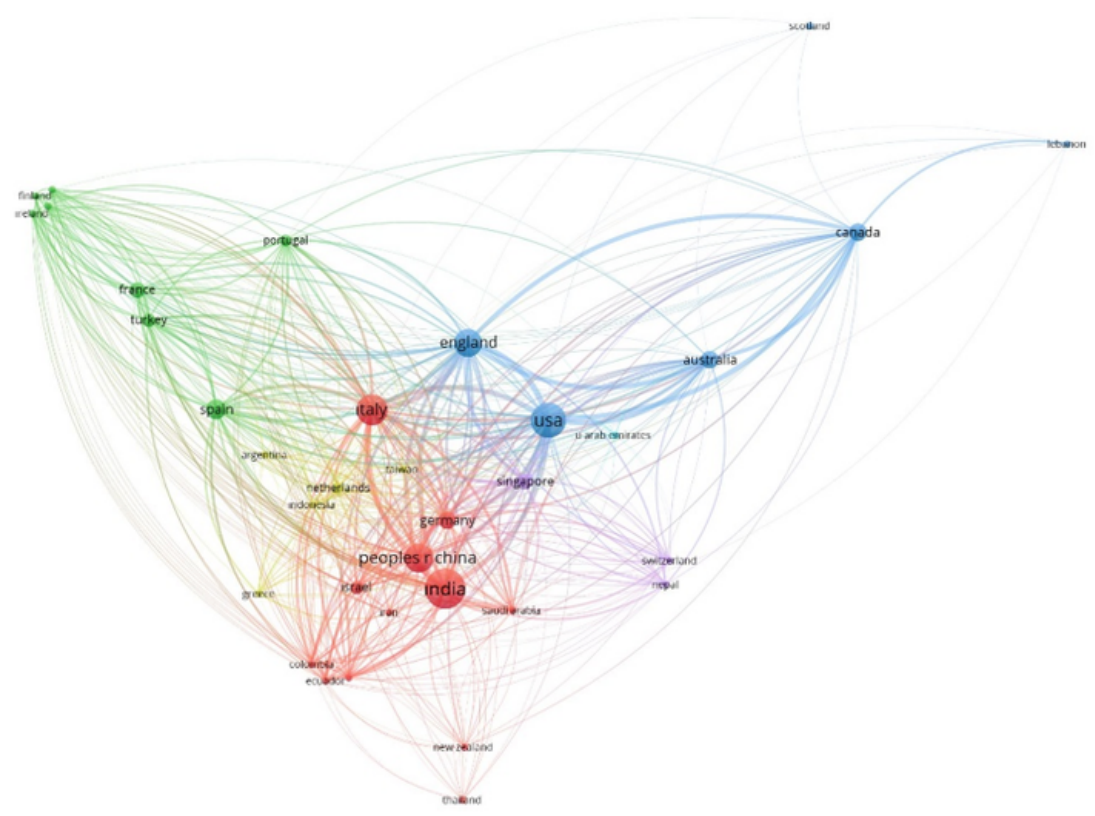

As vosviewer

\section{Figure 3}

\section{Network visualization maps of COVID-19 Eye research}

A. The strength of bibliographic country coupling linkages is displayed

B. The co-occurrence analysis of high-frequency keywords is displayed 